\title{
Hea Alguse programmi rakendavate ja mitterakendavate rühmade õpetajate hinnangud oma tegevusele lapsekeskse kasvatuse kontekstis
}

\author{
Maire Tuul $^{a}$, Tiia Õun ${ }^{\text {a1 }}$, Uljana Botvina ${ }^{a}$ \\ ${ }^{a}$ Tallinna Ülikooli haridusteaduste instituut
}

\begin{abstract}
Annotatsioon
Lapsekesksele kasvatusele üleminek on alushariduse valdkonnas olnud üks olulisimaid eesmärke alates Eesti taasiseseisvumisest. Selle eesmärgi täitmisel on õpetajatele abiks olnud Hea Alguse programm, milles rõhutatakse lapse individuaalsuse toetamist valikute võimaldamise ja last toetava pedagoogilise praktika kaudu. 2008. aastal tehtud kirjaliku küsitlusega selgitati välja, milliseid erinevusi esineb Hea Alguse programmi rakendavate ja mitterakendavate õpetajate hinnangutes oma tegevusele lapsekeskse kasvatuse kontekstis. Küsimustiku koostamise aluseks oli rahvusvahelise Hea Alguse Ühingu õpetajate hindamise standard. Uuringu tulemustest ilmneb, et Hea Alguse rühmade õpetajad rakendasid enda hinnangul oma tegevuses lapsekeskset kasvatust enam kui nende lasteaedade õpetajad, mis ei kuulu Hea Alguse programmi. 2016. aastal tehti sama uurimisvahendiga võrdlusuuring, et välja selgitada, kas Hea Alguse programmi rakendavate ja mitterakendavate õpetajate hinnangutes on varasema uuringuga võrreldes erinevusi. Küsitluse tulemustest selgub, et 2016. aastal olid Hea Alguse programmi mitterakendavate õpetajate hinnangud oma tegevusele lapsekeskse kasvatuse kontekstis oluliselt kõrgemad kui 2008. aastal ning ei erinenud enam statistiliselt olulisel määral Hea Alguse õpetajate hinnangutest.
\end{abstract}

Võtmesõnad: õpetajate hinnangud, Hea Algus, lapsekeskne kasvatus, koolieelne lasteasutus, alusharidus

\section{Sissejuhatus}

Koolieelsetel lasteasutustel on tähtis roll laste sotsiaalse, emotsionaalse, füüsilise ja kognitiivse arengu toetamisel ning võrdsete võimaluste tagamisel, et pakkuda neile kvaliteetset alusharidust. Alushariduse kvaliteedi parandamist peetakse Euroopa Liidus jätkusuutliku ja kaasava majanduskasvu tagamisel 
esmatähtsaks, kuna kvaliteetne alusharidus loob inimestele eeldused edukaks toimetulekuks koolis ja ühiskonnas (European Commission, 2014; UNESCO, 2000). Lapse õiguste konventsioonis (1996) on sätestatud, et igal lapsel on õigus haridusele, ning on rõhutatud laste võrdsete võimaluste ja huvide arvestamise printsiipi. Seega on igal lapsel õigus saada kvaliteetset alusharidust, hoolimata elukohast, rahvusest, keelest või muust eripärast (OECD, 2001). Kvaliteetse alushariduse aluseks peetakse Euroopas üldiselt lapsekeskset kasvatust, milles arvestatakse laste huvidega, tuginedes lapse vajadustele ja kogemustele (European Commission, 2014).

Eestis on rõhutatud vajadust minna täiskasvanust lähtuvalt kasvatuselt üle lapsekesksele kasvatusele juba rohkem kui 20 aastat. Seda üleminekut on toetatud lapsekeskse kasvatuse põhimõtete kajastamisega taasiseseisvunud Eesti alushariduse valdkonna riiklikes õppekavades (Alushariduse raamõppekava ..., 1999; Koolieelse lasteasutuse riiklik õppekava, 2008), aga ka arvukate õpetajatele pakutud koolitustega (Tuul, 2017). Riiklikele õppekavadele lisaks on õpetajate arusaama lapsekesksest kasvatusest oluliselt mõjutanud ka Hea Alguse programm, mis jõudis Avatud Eesti Fondi vahendusel Eestisse 1994. aastal (Põlluste, 2014) ning milles anti õpetajatele juhised lapsekeskse õpikeskkonna kujundamiseks ning lastele valikute tegemise ja iseseisvate otsuste langetamise võimaldamiseks. Hea Alguse programmi rakendamine aitas õpetajatel nende endi sõnul muuta nii oma arusaamu kvaliteetsest õppeprotsessist kui ka enda õpetamispraktikat (Ugaste, Õun, \& Tuul, 2008). Kuigi Hea Alguse koolituskeskus pakkus lapsekeskse kasvatuse koolitusi kõikidele soovijatele, sõltumata sellest, kas koolitusele tulijal oli plaanis hakata töötama Hea Alguse programmi järgi või mitte, näitasid 2008. aastal korraldatud õpetajauuringu tulemused suuri erinevusi Hea Alguse programmi rakendavate ja mitterakendavate õpetajate hinnangutes oma tegevusele lapsekeskse kasvatuse kontekstis. Nimelt selgus, et Hea Alguse õpetajad hindasid oma pedagoogilist tegevust tunduvalt lapsekesksemaks kui need õpetajad, kes ei kuulunud Hea Alguse programmi (Õun, Ugaste, Tuul, \& Niglas, 2010). Toetamaks senisest tõhusamalt lapsekesksete ideede levikut Eestis, kirjutati ka koolieelse lasteasutuse riiklikku óppekavva (2008) põhimõtted, mis sarnanesid Hea Alguse programmis esitatud lapsekeskse kasvatuse põhimõtetega.

Koolieelsete lasteasutuste õppekavad viidi uuenenud riikliku õppekavaga vastavusse 1. märtsiks 2009. Kuna õppekava on üks õpetajatöö põhidokumente, siis eeldati, et uuenenud õppekava toel ühtlustuvad peagi nii õpetajate arusaamad kvaliteetsest õppeprotsessi juhtimisest kui ka õpetajate õpetamispraktika. Samas näitasid 2014. aastal 25 Hea Alguse programmi mitterakendava õpetajaga läbi viidud kirjalik küsitlus ja nende tegevuse vaatlus, et õpetajad lähtusid oma tegevustes lapsekeskse kasvatuse põhimõtetest vaid 
osaliselt, kuigi nende endi sõnul oli nende pedagoogilise töö aluseks valdavalt just lapsekeskne õpikäsitus (Kimer, Tuul, \& Õun, 2016). Kuna nimetatud uuringus osalejate arv oli väike, siis tekkis küsimus, kuivõrd peegeldavad selle uuringu tulemused alushariduse valdkonnas ilmnevaid üldisi tendentse, st kas Hea Alguse programmi mitterakendavate õpetajate kõrge hinnang oma tegevusele lapsekeskse kasvatuse kontekstis on valdav või võib neid tulemusi seletada pigem valimi eripäraga. Näiteks on Spillane, Reiser ja Reimer (2002) arvanud, et õpetaja õpetamisarusaamades toimunud muutustest hoolimata võivad õpetajal puududa vajalikud teadmised, oskused ja ressursid oma pedagoogilise praktika muutmiseks. Seepärast otsustasime korrata 2008. aastal tehtud ISSA (International Step by Step Association) standardil põhinevat uuringut, mille eesmärk oli välja selgitada, kas Hea Alguse programmi rakendavate ja mitterakendavate õpetajate hinnangud oma pedagoogilisele tegevusele lapsekeskse kasvatuse kontekstis endiselt erinevad ning milles seisnevad ligikaudu kaheksa aastat pärast koolieelse lasteasutuse riikliku õppekava (2008) kehtima hakkamist korraldatud ja varasema uuringu tulemuste erinevused.

\section{Lapsekeskne kasvatus}

Arutelu selle üle, mida tähendab lapsekeskne lähenemine lapse õppimisele ja õpetamisele, on toimunud pidevalt läbi alushariduse ajaloo. Aktiivse diskussiooni fookuses on olnud nii lapsekeskse kasvatuse sisu kui ka võimalused arendada ja rakendada lapsekeskset óppekava erinevas hariduslikus ja kultuurilises kontekstis (Bredekamp \& Copple, 1997; Lee \& Tseng, 2008; Tzuo, 2007). Mitmed autorid on vastandanud lapsekeskset ja täiskasvanust lähtuvat kasvatust. Viimast neist on seotud biheivioristlike õpiteooriatega (Buchanan, Burts, Bidner, White, \& Charlesworth, 1998), milles õppimine saab nähtavaks eelkõige käitumise määras või viisis toimunud muutuse kaudu (Ertmer \& Newby, 1993; Kronqvist, 2011). Õpetajat nähakse täiskasvanust lähtuvas õpetamissuhtes sageli autoritaarsena, õpetamisel väärtustatakse akadeemilisi teadmisi ja pidevat kordamist ning protsessist olulisemaks peetakse tulemuse saavutamist (Pinnegar \& Erickson, 2010).

Mõistega lapsekeskne kasvatus on tähistatud väga erinevat laadi pedagoogilist praktikat (Chung \& Walsh, 2000; Tuul, 2017), kuid kõige sagedamini on seda seostatud Dewey progressiivsete vaadetega haridusele (Jeynes, 2007; Kelly, 2010; Ruto-Korir, 2010; Tzuo, 2007), Piaget' konstruktivistliku (Bainbridge, 2007; Stipek \& Byler, 1997) ja Võgotski sotsiaal-konstruktivistliku õpiteooriaga (Tzuo, 2007). Stipeki ja Byleri $(2004,2005)$ järgi on lapsekeskses praktikas olulisel kohal jagatud vastutus, õpetajapoolne laste õppimise ja sotsiaalse arengu toetamine ning tasakaal õpetaja kavandatud eesmärgipärase juhendamise ja 
laste initsiatiivist ning huvidest lähtumise vahel. Tuginedes konstruktivistlikule õpikäsitusele, tähtsustatakse lapsekeskses kasvatuses last kui aktiivset õppijat ning lapse terviklikku arengut, mida toetatakse mängulise, integreeritud óppeprotsessi kaudu (Bredekamp \& Copple, 1997; Doddington \& Hilton, 2007; Kwon, 2004, Murphy, 2004; Saracho \& Spodek, 2003). On autoreid, kes eristavad lapsekeskset kasvatust, kus õpetaja on õppimise juhtija ja laps juhtimisele alluv subjekt, ning lapsest lähtuvat kasvatust, kus õpetaja on õppimise toetaja ja laps otsuseid tegev aktiivne subjekt (Kinos \& Pukk, 2010). Rahvusvahelistes alushariduse aruteludes ja uuringutes kasutatakse siiski enam terminit lapsekeskne kasvatus, mida mõistetakse pedagoogilise kontseptsioonina, mille keskmes on laps kui aktiivne õppija ja tema terviklik areng (Bredekamp \& Copple, 1997; Doddington \& Hilton, 2007; Murphy, 2004) ning millest lähtuvas õppeprotsessis on rõhuasetus mängulisel, integreeritud õpetusel (Kwon, 2004; Saracho \& Spodek, 2003).

\section{Lapsekeskne kasvatus Eesti alushariduses ja Hea Alguse programm}

Lapsekeskse kasvatuse rakendamise ühe eeldusena nimetatakse demokraatlike põhimõtete ja väärtuste jagamist koolieelsetes lasteasutustes (Erwin \& Kipness, 1997). Peale Eesti Vabariigi taasiseseisvumist 1991. aastal väärtustati kogu Eesti haridussüsteemi uuendamisel demokraatlikke põhimõtteid. Haridusasutuste tegevuse sisulisel korraldamisel võeti suund lapse arengust lähtuvale käsitusele, mis vastandus nõukogude perioodi omale, mille keskmes oli õpetaja juhitud ja kontrollitud õppeprotsess, mis jättis tagaplaanile lapse õpitegevuse, holistilise arengu ja individuaalsuse. Ühtlasi pandi rõhk lapsesõbralikkusele, mida vastandati autoritaarsele, lapse vajadusi ja huvisid ignoreerivale kasvatusstiilile (Sarv, 1999). Samas ei olnud lapsekeskse kasvatuse põhimõtted Eestis ka varem tundmatud. 1930. aastatel rakendati paljudes Eesti koolides üldõpetuse ja õpilase individuaalse arengu arvestamise põhimõtteid ning propageeriti demokraatlikku koolikorraldust. Kuigi nõukogude perioodil olid kogu riigis kasutusel ühtsed programmid, säilis Eestis mõningal määral oma rahvuslik eripära, näiteks õppetegevus lasteaedades ja koolides toimus eesti keeles ning koostati ka eestikeelset õppekirjandust (Ruus \& Sarv, 2000). Haridussüsteemi demokratiseerimisele Eesti alushariduses ja esimeses kooliastmes aitas oluliselt kaasa 1994. aastal Eesti lasteaedades ja algkoolides käivitatud Hea Alguse programm.

Hea Alguse programmi eesmärk on toetada demokraatia ja lapsekesksete ideede levikut (Coughlin \& Walsh, 1996; Klaus, 2004), et suurendada perede osalust laste kasvatamisel ja toetada individualiseeritud õpetust lasteaias, aidates seeläbi kaasa laste suutlikkusele ise valikuid ja otsuseid teha. Programm on koostatud rahvusvahelise Hea Alguse Ühenduse (ISSA), Georgetowni Ülikooli 
ja Children's Resources Internationali (CRI) koostöös ning on mõeldud lastele sünnist kuni kümnenda eluaastani. Selle programmi alusel alustas 1994. aastal Eestis tööd 22 Hea Alguse rühma. Rühmade loomise eesmärk oli kujundada mudelrühmad Hea Alguse metoodika tutvustamiseks. 1996. aastal liitusid Hea Alguse programmiga ka mitmed Eesti koolid. Tööd alustas 13 esimest klassi Eesti eri koolides. Alates 1997. aastast on programmis osalenud vene õppekeelega klassid. 2007. aastal rakendati programmi metoodikat 250 lasteaiarühmas ja 150 klassis üle Eesti. Programmi levikut toetas Hea Alguse koolituskeskus, kus peale Hea Alguse lasteaedade ópetajate osalesid lapsekeskse kasvatuse koolitustel ka paljude teiste lasteaedade õpetajad. Eesti keeles on ilmunud lasteaiaõpetajatele materjalid demokraatliku kasvatuse edendamiseks lasteaias ja õpetaja tegevuse hindamiseks ning programmid Hea Alguse metoodika rakendamiseks töös 1-3aastaste ja 3-7aastaste lastega (Männamaa, 2006).

Hea Alguse programmi teoreetilistes alustes on esile toodud soovituslikud viisid, kuidas läheneda lapse arengule ja õppimisele, kasvukeskkonna loomisele ning demokraatlike põhimõtete rakendamisele koolieelses eas. Programmi rakenduslikus osas on esitatud põhimõtted rühma kasvukeskkonna kujundamiseks, lapse arengu jälgimiseks ja hindamiseks, õppetegevuste individualiseerimiseks ning lapsevanematega koostöö tegemiseks (Hansen, Kaufmann, \& Walsh, 1997). Programmis on kesksel kohal individualiseerimine, mille kohaselt peaks päevaplaan sobima iga lapse vajadustega ning valitud materjalid, õppemeetodid ja tegevused olema lastele eakohased, samuti tuleks last kaasata viisil, mis tekitab tal edutunde. Individualiseerimine toetab lapse iseseisvuse, aktiivsuse, valikuvabaduse ja vastutuse kujunemist. Õpetaja roll väljendub lapse arengu igakülgses toetamises individualiseerimise kaudu ning perekonna kaasamises lapse arengu hindamisse ja rühma tegevusse. Hea Alguse rühma õpikeskkond võimaldab lapsel teha valikuid, oma huvi realiseerida ja aktiivselt tegutseda. Seda põhimõtet toetavad Hea Alguse rühmaruumi tegevuskeskused, mis võimaldavad õpetajal tegevusi individualiseerida ning lastel aktiivselt õppida, mängida, teha valikuid ja tegutseda väikestes gruppides. Hea Alguse rühmade peamised keskused on kunsti-, klotsi-, kokandus-, loovmängu, kirjaoskuse, matemaatika ja käelise tegevuse, muusika, liiva ja vee ning teaduskeskus (Hansen et al., 1997).

Rahvusvahelistest uuringutest Hea Alguse programmi rakendamise kohta ilmneb, et programmis osalemine mõjutab positiivselt laste emotsionaalset, sotsiaalset ja intellektuaalset arengut ning toetab lapsekesksete ideede levikut õpetajate seas (Havlinova et al., 2004; Kazimade et al., 2003). Eesti lasteaiaõpetajate uuring näitab, et Hea Alguse programmi rakendamine toetab õpetajate professionaalsust, aidates neil paremini mõista ja analüüsida pedagoogilisi protsesse ning lapse arengut (Ugaste \& Õun, 2007). Eesti õpetajate hulgas 
tehtud õppekava rakendusuuringutest ilmneb, et kuigi lapsekeskse kasvatuse ideid peetakse Eesti alushariduses valdavaks, leiavad lasteaiaõpetajad siiski, et õppetegevused lasteaias on ainekesksed ning õppekava ei võimalda üldõpetuse ja eri metoodika kasutamist (Treier, 2004). 2008. aasta uuringust, kus võrreldi Hea Alguse programmi rakendavate ja mitterakendavate õpetajate hinnanguid lapsekesksele tegevusele Eesti lasteaedades (Õun et al., 2010), selgub, et teatud määral on lapsekeskse kasvatuse põhimõtted Eesti lasteaedades rakendunud, aga Hea Alguse lasteaedade õpetajad lähtuvad lapsekesksest kasvatusest oluliselt enam võrreldes Hea Alguse programmi mitterakendavate lasteaedade õpetajatega. Hea Alguse õpetajad pööravad enam tähelepanu lapse valikuvõimalustele, iseseisvuse toetamisele, lastevahelisele koostööle, tolerantsusele, aktiivsele õppimisele ja loovuse kujundamisele. 2016. aastal tegime sama uurimismetoodika alusel uuringu, milles võrdlesime Hea Alguse programmi rakendavate ja mitterakendavate õpetajate hinnanguid omavahel ning ka varasema, 2008. aastal korraldatud uuringu tulemustega. Siinses uurimuses otsime vastuseid järgmistele küsimustele.

- Millised on õpetajate hinnangud oma tegevusele lapsekeskse kasvatuse kontekstis, pidades silmas õpetaja ja lapse vahelist suhtlust, koostööd lapsevanematega, õpetaja töö planeerimist, lapsest lähtuvate õppemeetodite rakendamist ja kasvukeskkonna kujundamist?

- Millised on erinevused Hea Alguse programmi rakendavate ja mitterakendavate õpetajate hinnangute vahel?

- Mille poolest erinevad 2016. aastal korraldatud uuringu tulemused 2008. aastal korraldatud uuringu tulemustest?

Hüpoteesidena oletame, et 1) õpetajate hinnangud oma tegevusele lapsekeskse kasvatuse kontekstis on kõrged ning 2) olulised erinevused Hea Alguse programmi rakendavate ja mitterakendavate õpetajate hinnangutes puuduvad. Hüpoteeside püstitamisel tuginesime 25 õpetajat hõlmanud uuringu tulemustele, mis näitasid, et õpetajate enda hinnangul lähtuvad nad oma tegevuses valdavalt lapsekeskse kasvatuse põhimõtetest (vt Kimer et al., 2016). Samuti on hüpoteeside püstitamise aluseks 2013. aastal 347 rühmaõpetajaga tehtud kirjaliku küsitluse tulemused, mille kohaselt on õpetajad üldiselt väga rahul nii koolieelse lasteasutuse riikliku õppekavaga kui ka oma lasteaia õppekavaga (Tuul, Mikser, Neudorf, \& Ugaste, 2015). Selle põhjal võib oletada, et õpetajad on omaks võtnud ka õppekavades välja toodud lapsekeskse õpikäsituse. 


\section{Metoodika}

\section{Küsimustik}

Kuna soovisime teha võrdlusuuringut varasema uuringuga (vt Õun et al., 2010), võtsime selle aluseks struktureeritud kirjaliku küsimustiku, mis on koostatud Hea Alguse õpetajate tegevuse hindamise rahvusvahelisest standardist (ISSA, 2002) lähtudes. ISSA standard tugineb Hea Alguse programmis välja töötatud põhimõtetele, kus värrtustatakse õpetajate demokraatlikku ja lapsekeskset tegevust (ISSA, 2008). Käsitletavad valdkonnad hõlmavad suhteid rühmas, koostööd peredega, õpetaja pedagoogilist tegevust kavandamisel, hindamisel, õpetamisstrateegiate valimisel, keskkonna kujundamisel, kaasamisel ja enese arendamisel (ISSA, 2010). Igas valdkonnas on esitatud väited, mis iseloomustavad õpetaja lapsekesksest kasvatusest lähtuvat tegevust.

Uuringutes on leitud, et ISSA õpetaja standard on valiidne instrument õpetajate tegevuse hindamisel ja samuti efektiivne vahend õpetaja enesehindamisel (Peterson et al., 2016; Vonta, 2004). Kokku oli küsimustikus 66 väidet õpetaja tegevuse kohta ning need jaotusid viide valdkonda: õpetaja ja lapse vaheline suhtlus, koostöö lapsevanematega, ópetaja töö planeerimine, lapsest lähtuvate õppemeetodite rakendamine ja kasvukeskkonna kujundamine. Õpetajatel tuli viiepallisel sagedusskaalal ( 5 - alati, 4 - sageli, 3 - vahetevahel, 2 - harva ja 1 - mitte kunagi) hinnata, kui sageli nad väidetes esitatut teevad.

\section{Valim}

Nii 2008. aastal kui ka 2016. aastal korraldatud uuringus püüdsime ankeedi edastada võimalikult paljudele Hea Alguse rühmas töötavatele õpetajatele. Hea Alguse rühmas mittetöötavad õpetajad valisime Hea Alguse õpetajatega samadest piirkondadest. Kuna Hea Alguse rühmade kohta ametlik register puudub, siis lähtusime õpetajate otsingul 2008. aastal mittetulundusühingust Hea Algus saadud Hea Alguse rühmade nimekirjast. Rühmad, milles 2016. aastal enam Hea Alguse programmi ei rakendatud, asendasime kordusuuringus rühmadega, mille kohta saime teavet ka lasteaedade kodulehtedelt või Hea Alguse õpetajatelt.

Küsitluse korraldamiseks kontakteerusime esmalt valimisse sattunud lasteaedade direktoritega ning küsisime neilt luba uuringu tegemiseks lasteaias. Direktoritelt saime ka nende õpetajate kontaktandmed, kes olid andnud uuringus osalemiseks nõusoleku. Küsimustikud saatsime õpetajatele 2008. aastal paberil ning 2016. aastal e-posti teel või andsime need üle käest kätte. Küsimustiku täitmine oli õpetajatele vabatahtlik. Kui 2008. aastal osales uuringus 150 Hea Alguse programmi rakendavat ja 158 Hea Alguse programmi mitterakendavat õpetajat, siis 2016. aastal oli küsimustikule vastajate arv vastavalt 99 ja 106. Ülevaade õpetajate taustandmetest on tabelis 1. 
Tabel 1. 2008. ja 2016. aastal uuringus osalenud Hea Alguse programmi rakendavate ja mitterakendavate õpetajate jaotumine vanuse ja haridustaseme järgi

\begin{tabular}{|c|c|c|c|c|c|c|c|c|}
\hline & \multicolumn{3}{|c|}{2008} & \multicolumn{3}{|c|}{2016} & \multicolumn{2}{|c|}{2008 ja 2016} \\
\hline & $\mathrm{HA}$ & MHA & $\begin{array}{l}\text { HA ja } \\
\text { MHA }\end{array}$ & $\mathrm{HA}$ & $\mathrm{MHA}$ & $\begin{array}{l}\text { HA ja } \\
\text { MHA }\end{array}$ & $\mathrm{HA}$ & MHA \\
\hline & $\%$ & $\%$ & $x^{2}$ & $\%$ & $\%$ & $x^{2}$ & $x^{2}$ & $x^{2}$ \\
\hline \multicolumn{9}{|l|}{ Haridustase } \\
\hline $\begin{array}{l}\text { Mittepedagoogiline } \\
\text { keskeri- või kõrgharidus }\end{array}$ & 5,3 & 5,7 & & 12,1 & 8,5 & & & $56,07^{* *}$ \\
\hline $\begin{array}{l}\text { Pedagoogiline } \\
\text { keskeriharidus }\end{array}$ & 38,0 & 55,7 & $10,43^{* *}$ & 14,1 & 10,4 & 1,614 & $18,07^{* *}$ & \\
\hline $\begin{array}{l}\text { Pedagoogiline } \\
\text { kõrgharidus }\end{array}$ & 56,7 & 38,6 & & 73,7 & 81,1 & & & \\
\hline \multicolumn{9}{|l|}{ Vanus } \\
\hline Kuni 30 a & 14,0 & 14,6 & & 20,2 & 20,8 & & & 2,69 \\
\hline $31-50 a$ & 64,7 & 63,3 & 0,06 & 49,5 & 53,8 & 0,62 & 5,66 & \\
\hline Üle 50 a & 21,3 & 22,2 & & 30,3 & 25,5 & & & \\
\hline
\end{tabular}

Märkus. HA - Hea Alguse programmi rakendavad õpetajad; MHA - Hea Alguse programmi mitterakendavad õpetajad; $X^{2}$ - hii-ruut-statistiku väärtus; ${ }^{* *}-p<0,01$.

Nagu näha tabelist 1, on õpetajate jaotumine vanusegrupiti eri valimites üsna sarnane, samuti ei esine 2016. aasta uuringu põhjal statistiliselt olulisi erinevusi Hea Alguse programmi rakendavate ja mitterakendavate õpetajate haridustasemes. Samas oli 2008. aastal tehtud uuringus pedagoogilise kõrgharidusega õpetajate osakaal Hea Alguse õpetajate hulgas statistiliselt oluliselt suurem kui nende õpetajate hulgas, kes ei rakenda Hea Alguse programmi. Statistiliselt oluline erinevus ilmnes õpetajate haridustasemes ka 2008. ja 2016. aasta uuringute valimite võrdlemisel. Nimelt on viimasena tehtud uuringus pedagoogilise kõrgharidusega õpetajate osakaal oluliselt suurem kui esialgses uuringus. Sellist erinevust võib osaliselt selgitada kõrgharidusega õpetajate osakaalu üldise suurenemisega Eesti koolieelsetes lasteasutustes. Näiteks oli 2008/2009. õppeaastal Eesti hariduse infosüsteemi järgi koolieelsete lasteasutuste õpetajatest 52\% kõrgharidusega, samas kui 2015/2016. õppeaastal oli kõrgharidusega õpetajate osakaal juba 66\%. Kuna 2016. aasta uuringus oli kõrgharidusega õpetajate osakaal suurem kui koolieelsetes lasteasutustes üldiselt, siis võib arvata, et valimi kujunemist mõjutas ka küsimustiku edastamine interneti teel. 


\section{Andmeanalüïs}

Uuringu tulemusi analüüsisime andmetöötlusprogrammiga SPSS 19.0. Valimi kirjeldamiseks ja tulemustest esmase ülevaate saamiseks kasutasime kirjeldava statistika meetodeid ning gruppide võrdlemiseks üldistava statistika meetoditest Studenti $t$-testi (paariviisiline võrdlus, arvtunnused) ja hii-ruut-testi (kahe või enama grupi võrdlus, nimi- või järjestustunnused) $(p \leq 0,05)$. Lisaks arvutasime mõju suuruste (kahe keskmise vahelise standardiseeritud erinevuse) leidmiseks Coheni $d$ statistiku, mis näitab mõju suurust standardhälbe ühikutes. Coheni $d$ väärtusi $0,2-0,49$ võib tõlgendada kui väikest mõju, väärtusi 0,5-0,79 kui keskmist ja väärtusi üle 0,79 kui suurt mõju (Cohen, 1977). Et õpetajate tulemusi oleks võimalik võrrelda ka valdkonniti, arvutasime valdkonda kuuluvate üksiktunnuste keskmiste väärtuste põhjal koondtunnuste keskmised väärtused. Tekkinud koondtunnuste reliaabluskoefitsiendid (Cronbachi alfa) on esitatud tabelis 2 .

Tabel 2. Valdkondade reliaabluskoefitsiendid

\begin{tabular}{lcc}
\hline Valdkond & Tunnuste arv & Cronbachi alfa \\
\hline Õpetaja ja lapse vaheline suhtlus & 11 & 0,718 \\
\hline Koostöö lapsevanematega & 19 & 0,841 \\
\hline Õpetaja töö planeerimine & 10 & 0,753 \\
\hline Lapsest lähtuvate õppemeetodite rakendamine & 19 & 0,904 \\
\hline Kasvukeskkonna kujundamine & 7 & 0,712 \\
\hline
\end{tabular}

\section{Tulemused}

Järgnevalt esitame nii 2008. kui ka 2016. aasta uuringu tulemused viies valdkonnas, tuginedes Hea Alguse programmi rakendavate ja mitterakendavate õpetajate hinnangute võrdlusele. Lisaks analüüsime, mille poolest erinevad hilisema uuringu tulemused varasema uuringu omadest.

\section{Õpetaja ja lapse vaheline suhtlus}

Selle valdkonna küsimustega soovisime välja selgitada, kui sageli kasutavad õpetajad lastega suhtlemisel last aktsepteerivat suhtlusstiili, arvestavad lapse eripära ja toetavad lastevahelisi kontakte. 2016. aastal tehtud küsitlusest selgus, et Hea Alguse programmi rakendavate ja mitterakendavate õpetajate hinnangute vahel puuduvad kõikide väidete puhul statistiliselt olulised erinevused (tabel 3). 


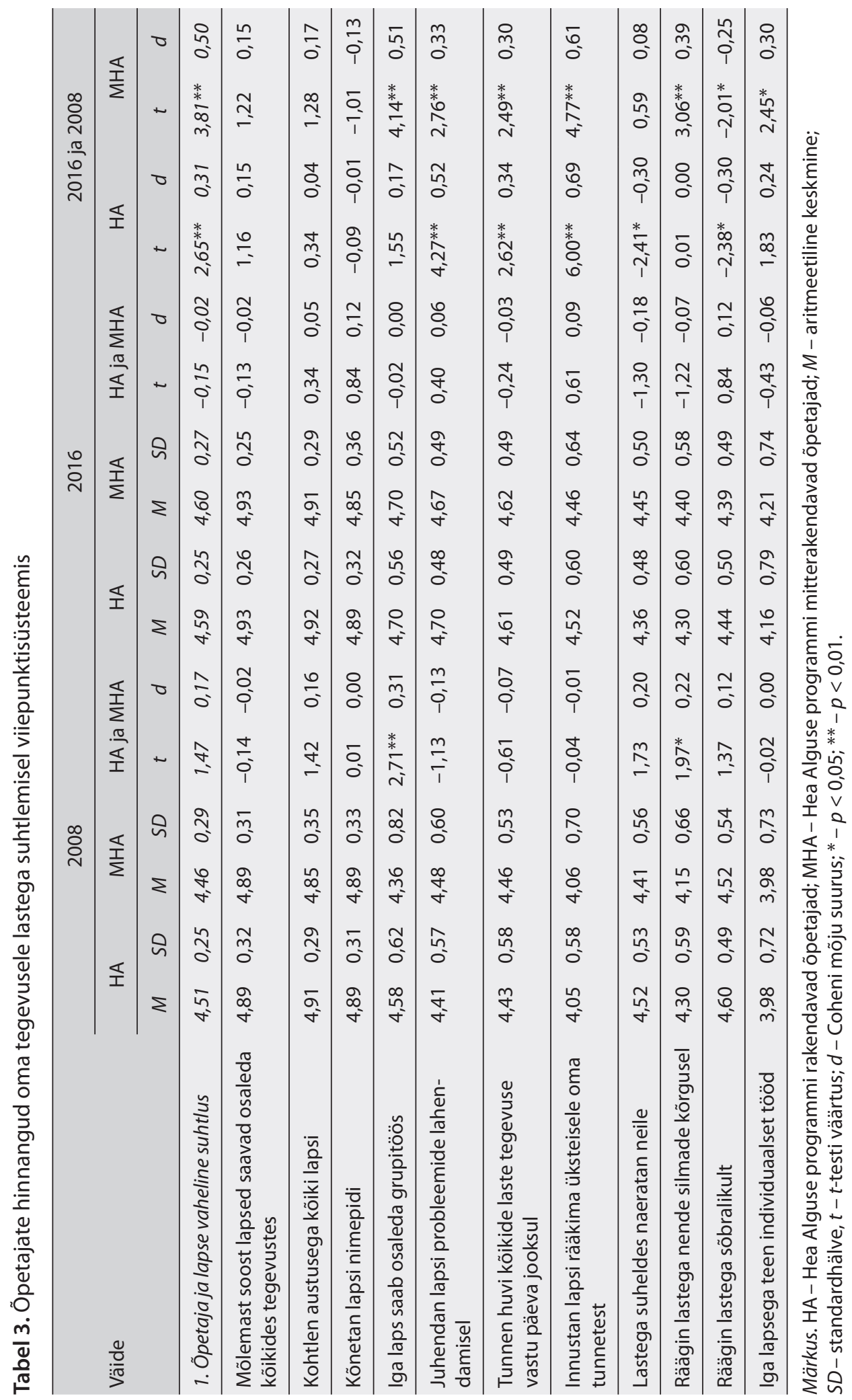


Nii Hea Alguse programmi rakendavate kui ka mitterakendavate õpetajate hinnangul teevad nad selles valdkonnas nimetatud tegevusi peaaegu alati (valdkonna koondhinnangud on vastavalt $M=4,59$ ja $M=4,60$ ). Kõige sagedamini võimaldavad Hea Alguse õpetajad enda hinnangul mõlemast soost lastel osaleda kõikides tegevustes, kohtlevad austusega kõiki lapsi ja kaasavad neid võrdselt grupitöösse, kõnetavad lapsi nimepidi ning juhendavad neid probleemide lahendamisel. Mõnevõrra harvem, kuid siiski sageli naeratavad õpetajad lastega suheldes neile, räägivad lastega nende silmade kõrgusel ja teevad iga lapsega individuaalset tööd. Hea Alguse programmi mitterakendavate rühmade õpetajate kõrgeimad ja madalaimad hinnangud selles valdkonnas on sarnased Hea Alguse õpetajate omadega.

Eri aastatel korraldatud uuringute tulemuste võrdlusest selgub, et 2016. aastal olid nii Hea Alguse programmi rakendavate kui ka mitterakendavate õpetajate hinnangud oma tegevusele suhtluse valdkonnas statistiliselt oluliselt kõrgemad kui 2008. aastal. Kõige suurem muutus on toimunud tundeõpetuses. Nimelt ilmneb, et 2016. aasta uuringus osalenute hinnangul innustavad nad lapsi üksteisele oma tunnetest rääkima oluliselt sagedamini, kui seda tegid 2008. aasta uuringus osalenud. Võrreldes 2008. aastal uuringus osalenud Hea Alguse õpetajatega juhendavad 2016. aastal uuringus osalenud Hea Alguse õpetajad enda hinnangul oluliselt sagedamini ka lapsi probleemide lahendamisel ning tunnevad huvi kõikide laste tegevuste vastu, samas räägivad nad lastega sõbralikult ja naeratavad neile veidi harvem. Hea Alguse programmi mitterakendavate rühmade õpetajate hinnangud on kahe uuringu tulemuste võrdluses enamiku väidete puhul tõusnud. Peale selle, et 2016. aastal uuringus osalenud õpetajad innustavad sagedamini lapsi rääkima oma tunnetest, on nende hinnangud oma tegevusele lapsekeskse kasvatuse skaalal 2008. aastal uuringus osalenud õpetajate omadest statistiliselt oluliselt kõrgemad ka laste juhendamise, nende tegevusest huvitumise, rääkima innustamise, rühmatöö võimaldamise ja individuaalse töö tegemise puhul. Samamoodi nagu Hea Alguse õpetajad, hindasid Hea Alguse programmi mitterakendavad õpetajad 2016. aastal lastega sõbralikult rääkimist veidi madalamalt kui 2008. aastal.

\section{Koostöö lapsevanematega}

Koostöö valdkonna küsimustega selgitasime välja, kui sageli pööravad õpetajad tähelepanu infovahetusele lapsevanematega ja kaasavad lapsevanemaid rühma tegevustesse. Kui 2008. aasta uuringus olid enamiku väidete korral Hea Alguse programmi rakendavate ja mitterakendavate õpetajate hinnangutes statistiliselt olulised erinevused ning Hea Alguse õpetajate hinnangud olid oluliselt kõrgemad, siis 2016. aastal tehtud küsitluses ilmnes uuritud õpetajate hinnangute vahel statistiliselt oluline erinevus vaid kahe väite puhul (tabel 4). 


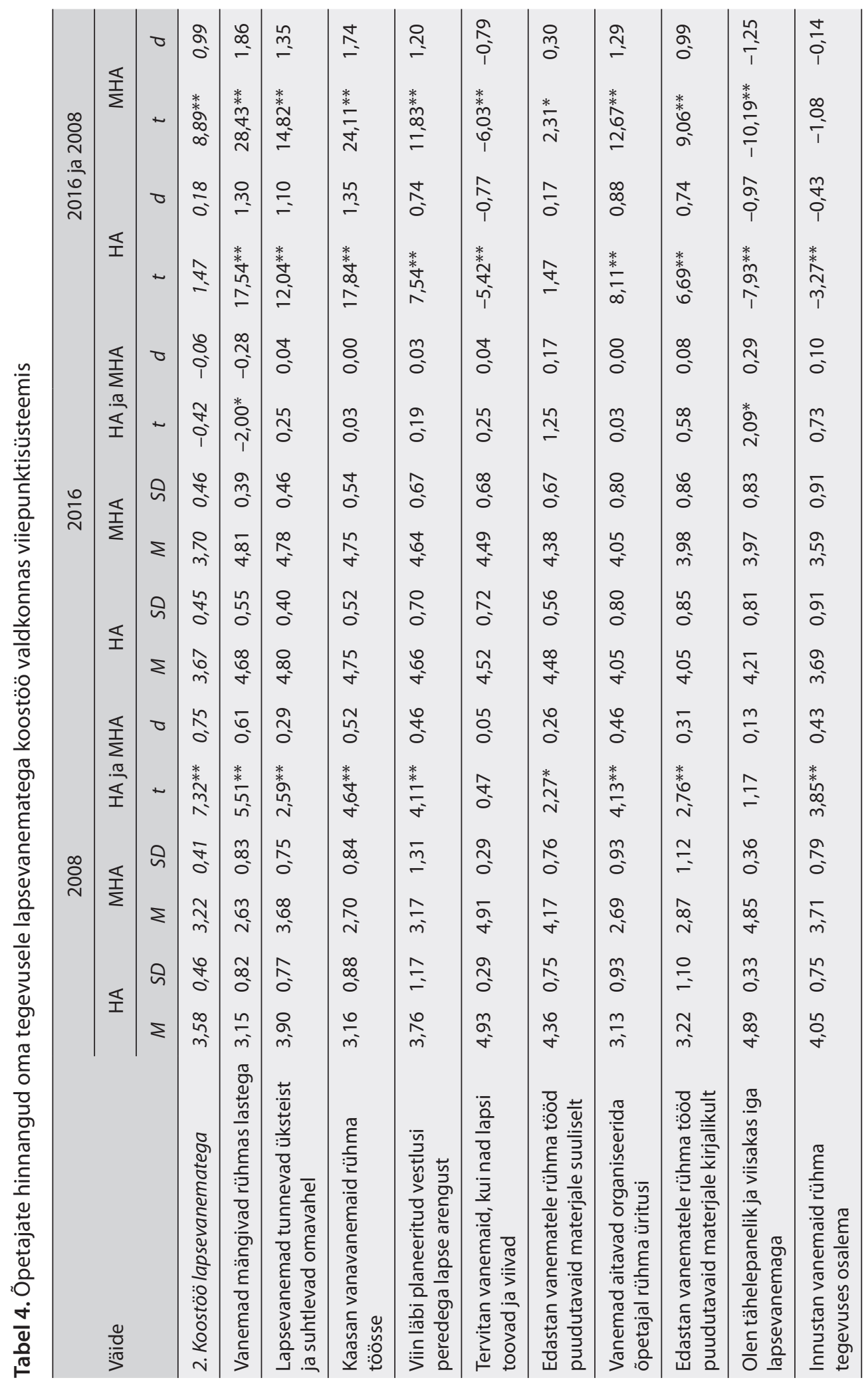




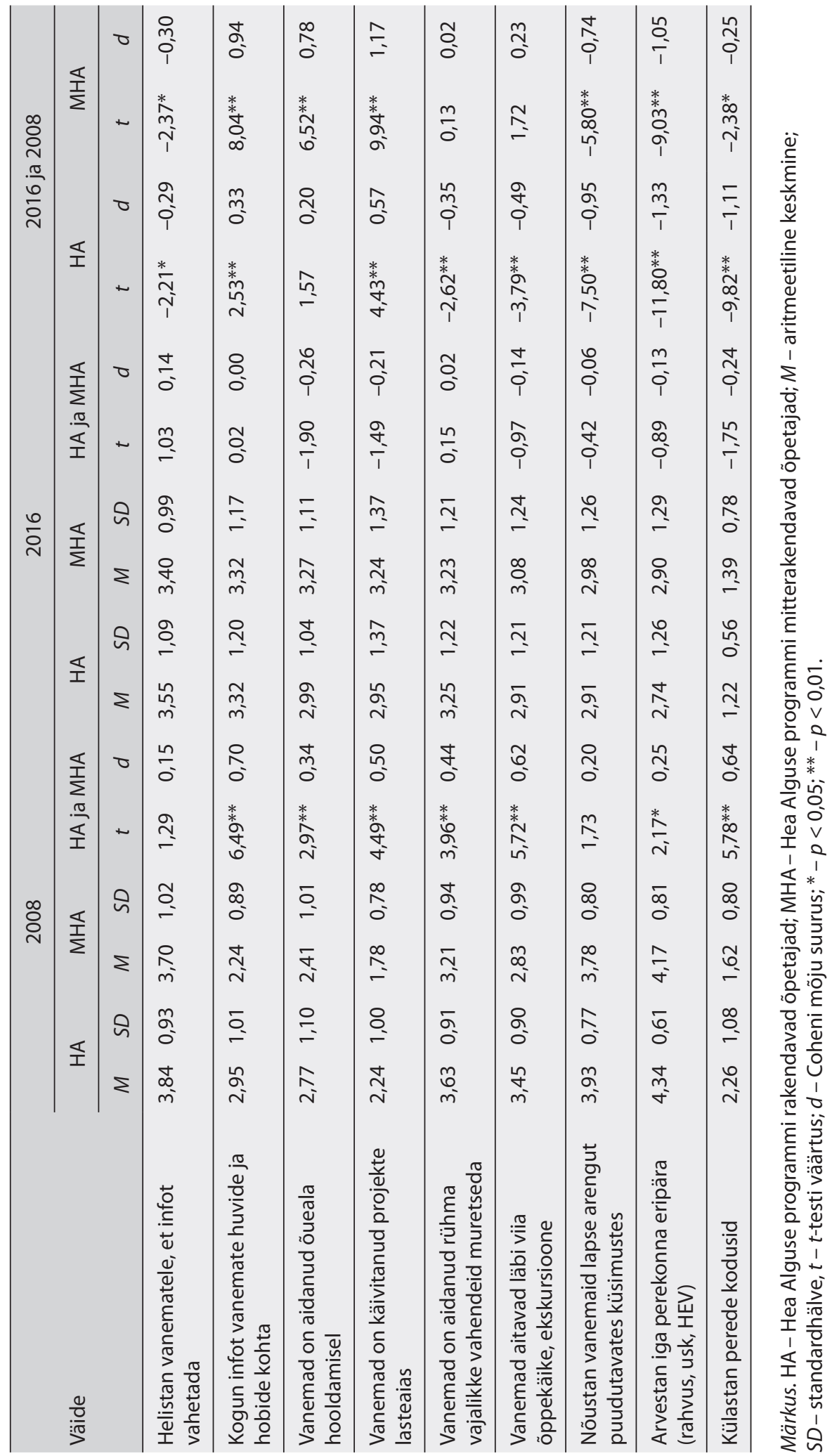


Tulemustest selgus, et Hea Alguse programmi mitterakendavate õpetajate hinnangul mängivad lapsevanemad rühmas lastega sagedamini kui Hea Alguse rühma õpetajate hinnangul ning Hea Alguse rühma õpetajad on enda hinnangul veidi sagedamini tähelepanelikud ja viisakad iga lapsevanema suhtes kui need õpetajad, kes ei rakenda Hea Alguse programmi. Nii Hea Alguse programmi rakendavate kui ka mitterakendavate õpetajate hinnangul teevad nad lapsevanematega koostöö valdkonnas nimetatud tegevusi pigem sageli või vahetevahel (valdkonna koondhinnangud olid vastavalt $M=3,67$ ja $M=3,70$ ) ning valdkonna koondtulemuse poolest grupid statistiliselt olulisel määral ei erinenud. Hea Alguse rühma õpetajad on kõige sagedasemaks hinnanud rühma lapsevanemate vahelist suhtlust, vanemate mängu lastega, vanavanemate kaasamist rühma töösse ja arenguvestluste korraldamist. Madalaimalt on Hea Alguse rühma õpetajad hinnanud laste kodude külastamist, perede eripära arvestamist, vanematega koostööd õppekäikude korraldamisel ja vanemate nõustamist laste arengut puudutavates küsimustes. Neid tegevusi teevad õpetajad enda hinnangul harva või vahetevahel. Hea Alguse programmi mitterakendavate õpetajate kõrgeimad ja madalaimad hinnangud selles valdkonnas on sarnased Hea Alguse õpetajate omadega.

Võrreldes 2008. ja 2016. aasta tulemusi, ilmneb, et mõlema valimigrupi õpetajate tulemused on enamiku väidete puhul statistiliselt oluliselt erinevad. Hea Alguse rühma õpetajate hinnangute võrdlusest selgub, et 2016. aasta uuringus on õpetajad statistiliselt olulisel määral kõrgemalt hinnanud, et kaasavad vanavanemaid rühma töösse, vanemad mängivad rühmas lastega, aitavad organiseerida üritusi ja suhtlevad omavahel ning õpetaja korraldab arenguvestlusi ja kogub infot vanemate huvide kohta. Samas on 2016. aasta uuringus mõne väite puhul Hea Alguse õpetajate hinnangud oluliselt madalamad kui varasemas uuringus. Näiteks on õpetajad madalamalt hinnanud, et arvestavad iga perekonna eripära, nõustavad vanemaid lapse arengu küsimustes, on viisakad iga lapsevanemaga ning tervitavad vanemaid, kui nad lapsi toovad ja viivad. Hea Alguse programmi mitterakendavate õpetajate hinnangute vahel ilmnevad kahe uuringu võrdluses enamiku väidete puhul statistiliselt olulised erinevused, mis on sarnased Hea Alguse rühma õpetajate hinnangutes ilmnenud erinevustega.

\section{Õpetaja töö planeerimine}

Õpetaja töö planeerimise valdkonnas selgitasime välja õpetajate hinnangud lapsekesksete õppe- ja kasvatustegevuste kavandamise ja läbiviimise sagedusele. 2016. aastal tehtud küsitlusest selgus, et Hea Alguse programmi rakendavate ja mitterakendavate õpetajate hinnangute vahel puuduvad kõikide väidete puhul statistiliselt olulised erinevused (tabel 5). 


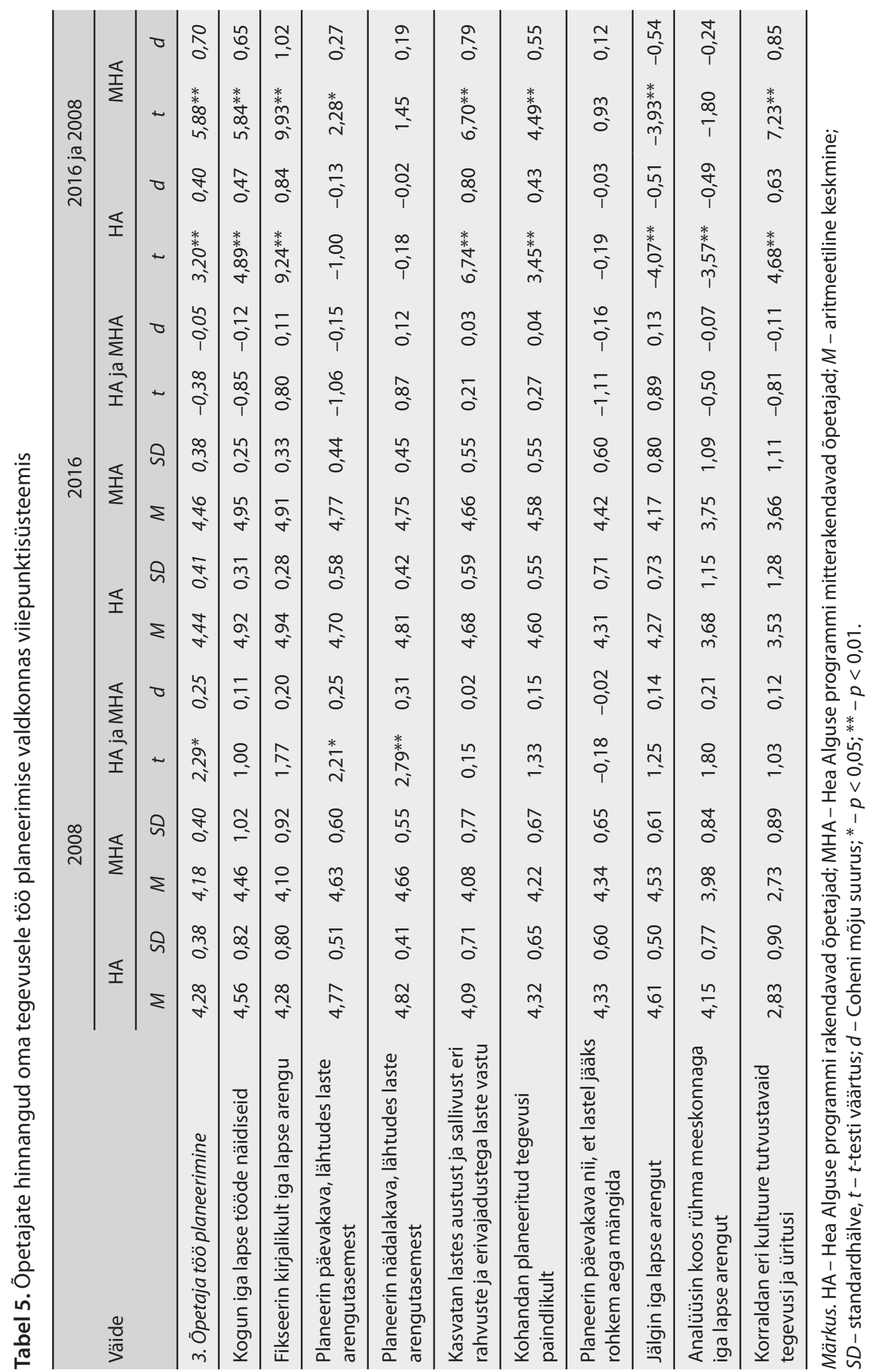


Nii Hea Alguse programmi rakendavate kui ka mitterakendavate õpetajate hinnangul teevad nad selles valdkonnas nimetatud tegevusi sageli või alati (valdkonna koondhinnangud on vastavalt $M=4,44$ ja $M=4,46$ ). Hea Alguse õpetajate hinnangul koguvad nad peaaegu alati iga lapse tööde näidiseid, fikseerivad kirjalikult iga lapse arengu ning lähtuvad tegevuste kavandamisel laste arengutasemest. Vahetevahel korraldavad õpetajad enda hinnangul eri kultuure tutvustavaid üritusi ja analüüsivad koos rühma meeskonnaga iga lapse arengut. Hea Alguse programmi mitterakendavate õpetajate hinnangud oma tegevusele olid sarnased Hea Alguse õpetajate omadega.

Võrreldes eri aastatel korraldatud uuringute tulemusi, selgub, et 2016. aastal olid nii Hea Alguse programmi rakendavate kui ka mitterakendavate õpetajate hinnangud oma tegevusele planeerimise valdkonnas enamiku väidete puhul statistiliselt olulisel määral kõrgemad kui 2008. aastal. Kõige suurem erinevus ilmnes nende väidete puhul, mis olid seotud lapse individuaalse arengu fikseerimisega, lapse töö näidiste kogumisega, lastes sallivuse kasvatamisega eri rahvuste ja erivajadustega laste vastu ja teisi kultuure tutvustavate üritustega. Samas on nii Hea Alguse programmi rakendavad kui ka mitterakendavad õpetajad võrreldes 2008. aasta uuringus osalenutega hinnanud statistiliselt olulisel määral madalamalt iga lapse arengu jälgimist ja koos rühma meeskonnaga laste arengu analüüsimist. Kui õpetajate keskmiste hinnangute põhjal jälgivad nad laste arengut praegu sageli, siis lapse arengut analüüsivad nad koos rühma meeskonnaga vahetevahel.

\section{Lapsest lähtuvate õppemeetodite rakendamine}

Õppe- ja kasvatusmeetodite küsimustega selgitasime välja, kui sageli õpetajad kasutavad selliseid õpistrateegiaid ja õppemeetodeid, mis soodustavad laste loovust, koostööd ja aktiivsust. 2016. aastal tehtud küsitlusest selgus, et Hea Alguse programmi rakendavate ja mitterakendavate õpetajate hinnangute vahel puuduvad kõikide väidete puhul statistiliselt olulised erinevused (tabel 6).

Nii Hea Alguse programmi rakendavate kui ka mitterakendavate õpetajate hinnangul teevad nad õppemeetodite valdkonna tegevusi peaaegu alati (valdkonna koondhinnangud on vastavalt $M=4,50$ ja $M=4,48$ ). Kõige sagedamini innustavad Hea Alguse õpetajad enda hinnangul lapsi loovalt tegutsema, mõtlema, arutlema ning tagavad lastele mängu- ja õppevahendite kättesaadavuse. Samuti hindasid õpetajad, et kasutavad sageli eri mänguliike ning lastel on sageli aega nii vaikseteks kui ka aktiivseteks tegevusteks. Mõnevõrra harvem loovad õpetajad enda hinnangul olukordi, kus lapsed lahendavad probleeme ühise eesmärgi saavutamise nimel, lapsed saavad planeerida, mis tegevusi nad teha soovivad, ja algatavad teemasid, mida käsitleda. Hea Alguse programmi mitterakendavate õpetajate kõrgeimad ja madalaimad hinnangud selles valdkonnas on sarnased Hea Alguse õpetajate omadega. 


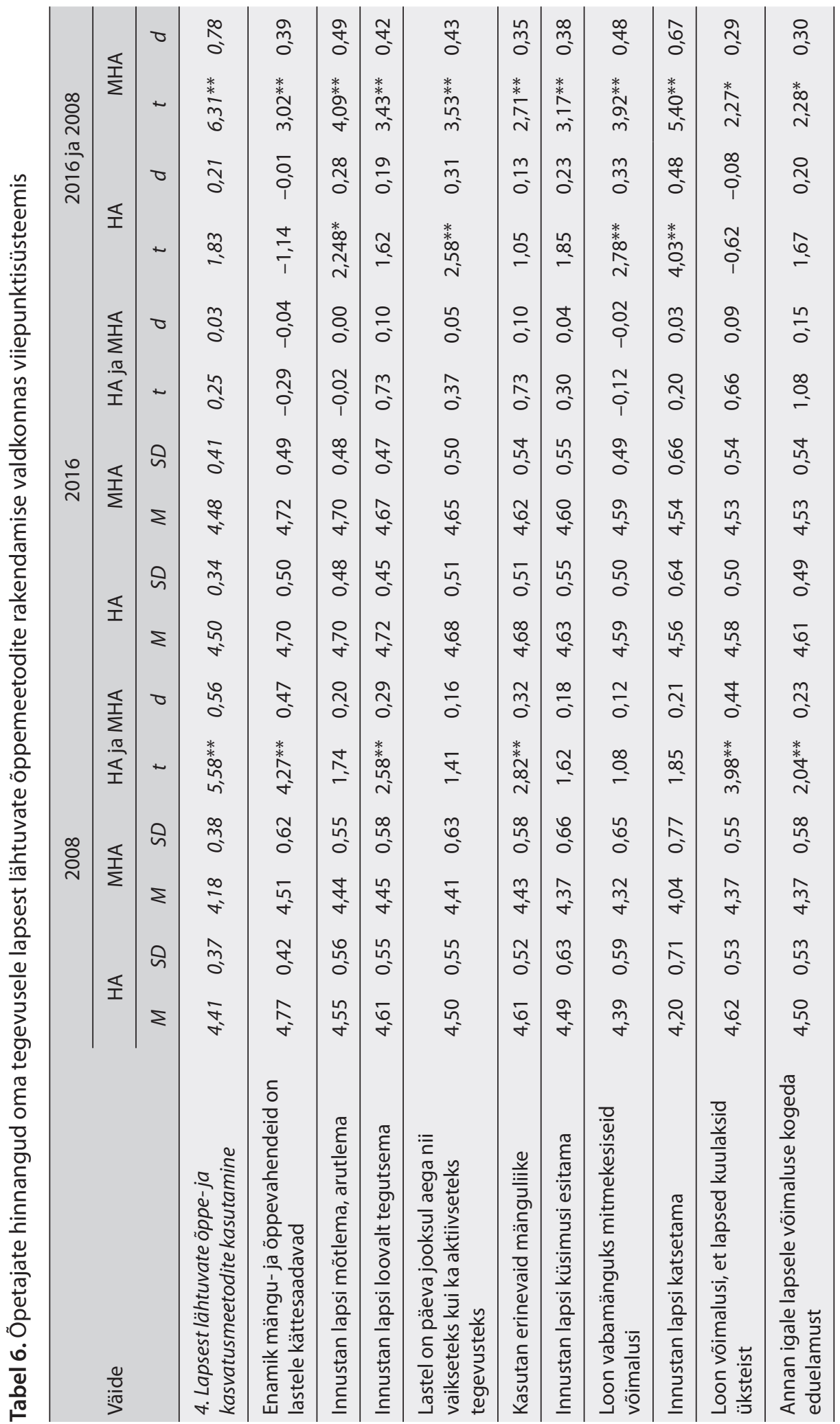




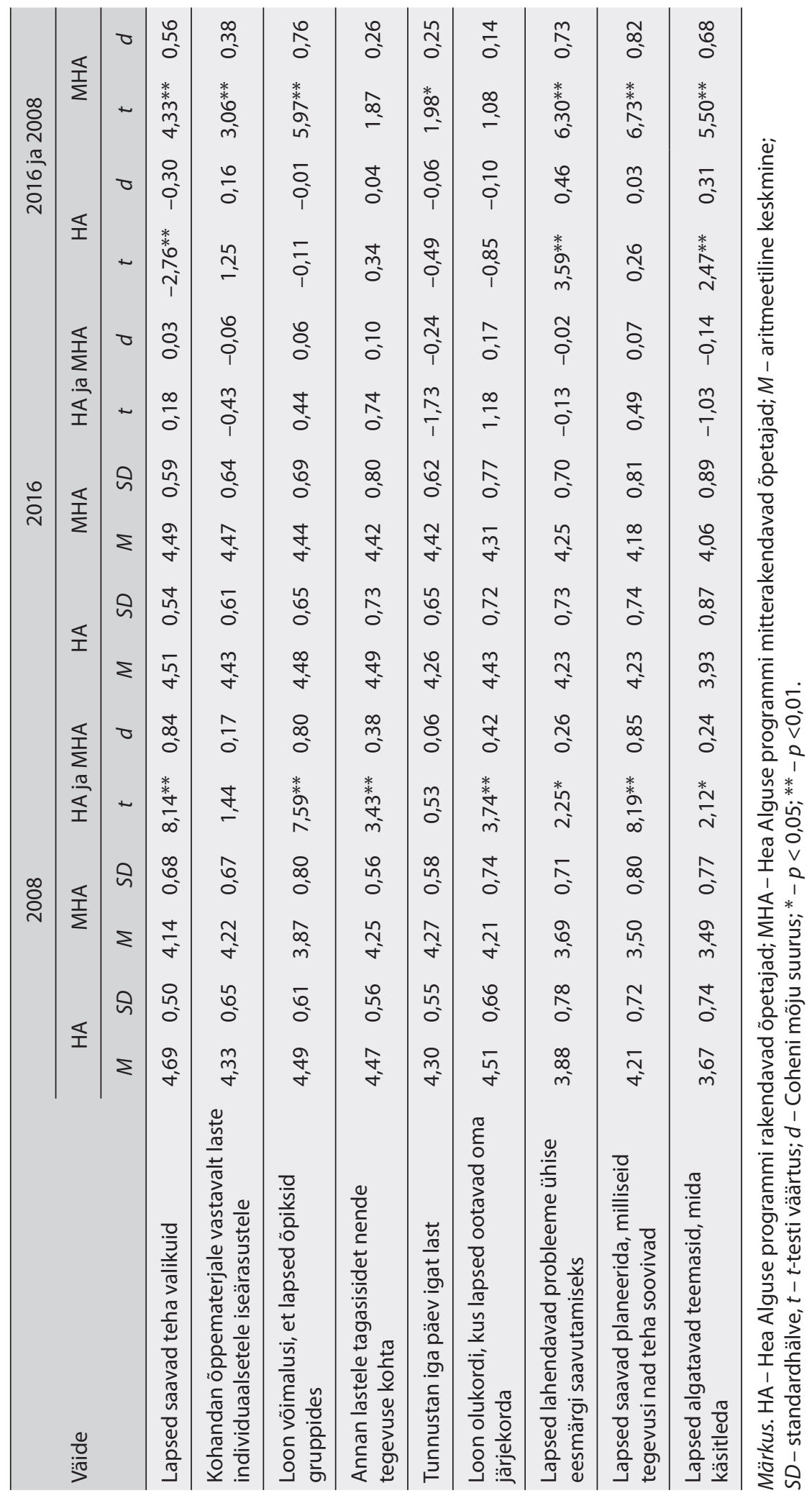


Võrreldes eri aastatel korraldatud uuringute tulemusi, selgus, et 2016. aastal olid Hea Alguse õpetajate tulemused mõne selle valdkonna väite korral statistiliselt olulisel määral kõrgemad kui 2008. aastal. Olulised erinevused ilmnesid nende väidete puhul, mis olid seotud laste innustamisega loovalt tegutsema, mõtlema, arutlema ja katsetama, lastele vabamänguks võimaluste loomisega ning laste algatusega teemade käsitlemisel ja probleemide lahendamisel. Samas lastele valikute võimaldamisel oli 2016. aastal uuringus osalenud Hea Alguse õpetajate keskmine hinnang 2008. aastal uuringus osalenud Hea Alguse õpetajate omast mõnevõrra madalam. Hea Alguse programmi mitterakendavate õpetajate hinnanguid kahe uuringu võrdluses analüüsides selgus, et 2016. aastal uuringus osalenute keskmised hinnangud olid peaaegu kõikide selle valdkonna tegevuste puhul statistiliselt oluliselt kõrgemad kui 2008. aastal uuringus osalenutel. Hea Alguse programmi mitterakendavad õpetajad hindasid ise, et lapsed lahendavad sagedamini probleeme, saavad sagedamini planeerida oma tegevusi ja algatada teemasid, mida käsitleda. Samuti kasutavad need õpetajad enda hinnangul varasemast sagedamini grupitööd ja innustavad lapsi katsetama.

\section{Kasvukeskkonna kujundamine}

Kasvukeskkonna kujundamise valdkonna küsimustega selgitasime välja, kui sageli pööravad õpetajad tähelepanu keskkonna aspektidele, mis toetavad lastel valikute tegemist ja aktiivset õppimist. Kui 2008. aastal tehtud uuringus olid Hea Alguse programmi rakendavate ja mitterakendavate õpetajate hinnangud kõikide väidete puhul statistiliselt olulisel määral erinevad, siis 2016. aastal sellised erinevused võrreldud õpetajagruppide hinnangutes puudusid (tabel 7).

Nii Hea Alguse programmi rakendavate kui ka mitterakendavate õpetajate hinnangud selle valdkonna tegevustele olid 2016. aastal väga kõrged (valdkonna koondhinnangud on vastavalt $M=4,52$ ja $M=4,52$ ). Õpetajate hinnangul on nende rühmas mööbel paigutatud peaaegu alati laste rühmatööd soodustavalt ja rühmaruum on jaotatud vastavalt tegevustele. Mõnevõrra harvem, kuid siiski sageli muretsevad õpetajad enda hinnangul õppevahendeid, mis peegeldavad rahvuslikke iseärasusi.

Võrreldes eri aastatel korraldatud uuringute tulemusi, selgus, et 2016. aastal oli Hea Alguse õpetajate hinnang statistiliselt olulisel määral kõrgem kui 2008. aastal vaid väite „Muretsen rühma õppe- ja mänguvahendeid, mis peegeldavad rahvuslikke iseärasusi“ korral. Hea Alguse programmi mitterakendavate õpetajate hinnanguid kahe uuringu võrdluses analüüsides ilmnes aga, et 2016. aastal uuringus osalenute keskmised hinnangud on peaaegu kõikide selle valdkonna tegevuste puhul statistiliselt olulisel määral kõrgemad kui varasemas uuringus osalenutel. Need õpetajad hangivad enda hinnangul varasemast sagedamini õppevahendeid, mis peegeldavad rahvuslikke iseärasusi, on jaotanud ruumi vastavalt tegevustele ja paigutanud mööbli laste rühmatööks sobivalt. 


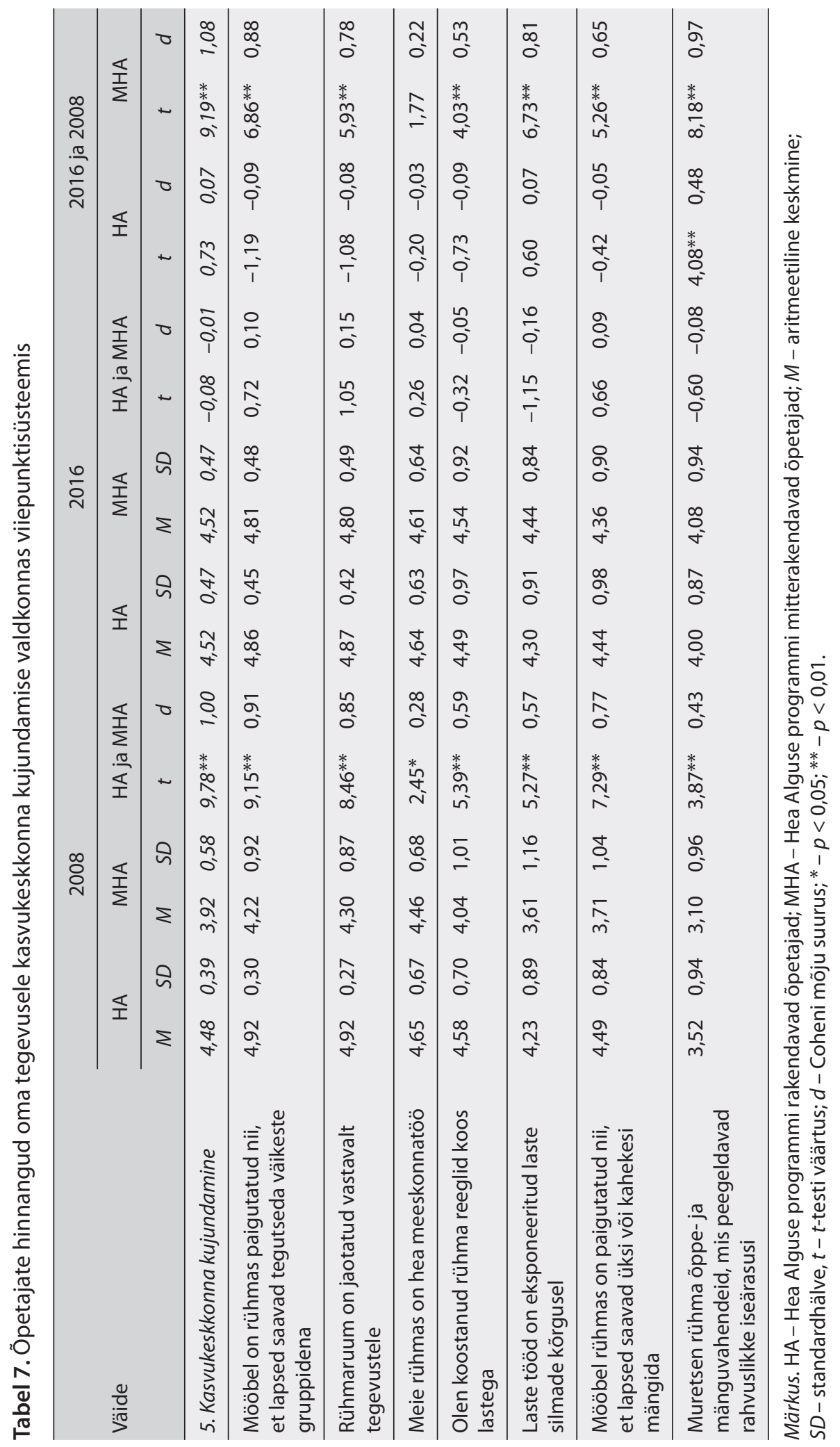


Kokkuvõtvalt võib öelda, et püstitatud hüpoteesid leidsid kinnitust: 1) õpetajate hinnangud oma tegevusele õpetaja ja lapse vahelise suhtluse, lapsevanematega koostöö, õpetaja töö planeerimise, lapsest lähtuvate õppemeetodite rakendamise ja kasvukeskkonna kujundamise valdkonnas on kõrged (hinnangute keskmine jäi vahemikku 3,7-4,6) ning 2) valdkondade koondtunnuste puhul puuduvad Hea Alguse programmi rakendavate ja mitterakendavate õpetajate hinnangute vahel statistiliselt olulised erinevused.

\section{Arutelu}

Artiklis tutvustatud uuringus otsiti vastuseid küsimusele, 1) millised on õpetajate hinnangud oma tegevusele lapsekeskse kasvatuse kontekstis, pidades silmas õpetaja ja lapse vahelist suhtlust, koostööd lapsevanematega, õpetaja töö planeerimist, lapsest lähtuvate õppemeetodite rakendamist ja kasvukeskkonna kujundamist; 2) millised on erinevused Hea Alguse programmi rakendavate ja mitterakendavate õpetajate hinnangute vahel; 3) mille poolest erinevad 2016. aastal korraldatud uuringu tulemused 2008. aastal korraldatud uuringu tulemustest. Hüpoteesina oletati, et 1) õpetajate hinnangud oma tegevusele lapsekeskse kasvatuse kontekstis on kõrged ning 2) olulised erinevused Hea Alguse programmi rakendavate ja mitterakendavate õpetajate hinnangutes puuduvad. Kokkuvõttes selgus uuringu tulemustest, et 2016. aastal olid Hea Alguse programmi mitterakendavate õpetajate hinnangud oma tegevusele lapsekeskse kasvatuse kontekstis oluliselt kõrgemad kui 2008. aastal ning need ei erinenud enam statistiliselt olulisel määral Hea Alguse õpetajate omadest.

2016. aastal korraldatud küsitlusest selgus, et õpetajad hindavad peaaegu kõikides uuritud valdkondades oma tegevust lapsekeskse kasvatuse kontekstis väga kõrgelt (hinnangute keskmine viiepunktisüsteemis oli üle 4,4), seega võib esimese hüpoteesi kinnitatuks lugeda. Ainus erand oli lapsevanematega koostöö valdkond, milles nimetatut teevad õpetajad enda hinnangul vahetevahel või sageli (hinnangute keskmine 3,7). Tendents, et Eesti õpetajad (aga ka direktorid) hindavad rühmaõpetajate tegevust lapsevanematega koostöö valdkonnas madalamalt kui teistes õpetaja töövaldkondades, tuli esile ka Petersoni jt (2016) uuringu põhjal. Lisaks leidsid nad samasuguse mustri Soome, Rootsi ja Ungari õpetajate ning direktorite vastustes. Probleemi laiemat ilmnemist kinnitab ka see, et nii OECD 2006. kui ka 2012. aasta materjalides on rõhutatud lapsevanematega koostöö tegemise olulisust. Kuna mitmed uurijad (Edwards, Sheridan, \& Knoche, 2008; Powell, Son, File, \& San Juan, 2010; Sylva, Melhuish, Sammons, Siraj-Blatchford, \& Taggart, 2004) on juhtinud tähelepanu asjaolule, et lapsevanemate kaasamine lasteaiaellu on positiivselt seotud laste kohanemise 
ning sotsiaalsete ja kognitiivsete saavutustega, siis vajab õpetajate koostöö lastevanematega edaspidi kindlasti põhjalikumat uurimist ning arendamist.

Hea Alguse programmi rakendavate ja mitterakendavate õpetajate hinnangute võrdlemisel ilmnes, et kui 2008. aastal erinesid võrreldavate valimigruppide hinnangud oma pedagoogilisele tegevusele statistiliselt olulisel määral 66 üksikväitest 38 puhul ja viiest valdkonna koondtunnusest nelja puhul, siis 2016. aastal puudutasid need erinevused vaid kaht üksikväidet lapsevanematega koostöö valdkonnas. Nimelt hindasid Hea Alguse õpetajad oma tähelepanelikkust ja viisakust iga lapsevanemaga suhtlemisel kõrgemalt ning laste ja lapsevanemate koosmängu rühmas harvemaks kui need õpetajad, kes ei juhindu Hea Alguse metoodikast. Kuna 2016. aasta uuringus Hea Alguse programmi rakendavate ja mitterakendavate õpetajate hinnangute keskmised valdkonniti peaaegu ei erinenud (keskmiste erinevus 0-0,03 punkti), siis leidis kinnitust ka teine hüpotees, et olulised erinevused nende õpetajagruppide hinnangutes puuduvad. See, miks õpetajate antud hinnangud oma lapsekesksele tegevusele, on ühtlustunud, võib tuleneda nii Hea Alguse programmis toodud lapsekesksete põhimõtete jõudmisest koolieelse lasteasutuse riiklikku õppekavva kui ka Hea Alguse programmi alusel mittetöötavate õpetajate aktiivsest osalemisest Hea Alguse koolituskeskuse lühematel või pikematel kursustel.

Kahe eri ajal korraldatud uuringu tulemused näitasid samas seda, et muutus on toimunud ka Hea Alguse õpetajate hinnangutes oma tegevusele. 2016. aastal olid võrreldes 2008. aastaga Hea Alguse programmi mitterakendavate õpetajate hinnangud statistiliselt olulisel määral kõrgemad kõikides valdkondades ning Hea Alguse õpetajate hinnangud õpetaja töö planeerimise ning õpetaja ja lapse vahelise suhtluse valdkonnas. Hea Alguse programmi mitterakendavate õpetajate hinnangutes on kõige suuremat edasiminekut näha kasvukeskkonna kujundamise ja lapsevanematega koostöö valdkonnas, milles 2008. aastal anti oma tegevusele kõige madalamad hinnangud ning mille korral oli ka erinevus Hea Alguse õpetajate hinnangutest varasemas uuringus kõige suurem. Kui kasvukeskkonna kujundamise valdkonnas on 2016. aastal Hea Alguse programmi mitterakendavate õpetajate hinnangud ka kõikide üksiktunnuste puhul kõrgemad kui 2008. aastal, siis lapsevanematega koostöö valdkonnas see nii ei ole. Nimelt märkisid 2008. aastal uuringus osalenud, et nad on tähelepanelikud ja viisakad iga lapsevanemaga, arvestavad iga perekonna eripära, tervitavad ja nõustavad vanemaid ning külastavad perede kodusid sagedamini, kui seda märkisid 2016. aastal uuringus osalenud. Viimaste hinnangul ei külasta nad laste kodusid peaaegu mitte kunagi ning lapsevanemaid nõustatakse ning iga perekonna eripäraga (rahvus, usk, erivajadused) arvestatakse vahetevahel. Ka Petersoni jt (2016) uuringust selgus, et lasteasutuste pedagoogid hindavad võrreldes teiste õpetaja tegevustega koostööd lapsevanematega kõige 
madalamalt. Uuringus juhitakse tähelepanu õpetajate ebapiisavatele teadmistele ja oskustele vanemate tulemuslikul kaasamisel. Niisamuti ilmnes Perssoni ja Tallberg Bromani (2017) uuringust, et õpetajad ja üliõpilased ei hinda lapsevanematega koostööd enda kõige tähtsamaks tööülesandeks, vaid esiplaanil on lapse areng. Samuti leidsid üliópilased, et neil ei ole piisavat ettevalmistust lapsevanematega koostööks. Uurijad toovad esile vastuolu, et Põhjamaades rõhutatakse alushariduses lasteasutuse ja perede võrdset vastutust, kuid vastutuse jagunemine osaliste vahel pole üheselt mõistetav (ibid.).

2016. aastal uuringus osalenud Hea Alguse õpetajad kasutavad võrreldes 2008. aastal uuringus osalenud Hea Alguse õpetajatega enda hinnangul sagedamini võimalusi, et lapsed algatavad teemasid, mida käsitleda, juhendavad lapsi probleemide lahendamisel ja innustavad neid rääkima üksteisele oma tunnetest. Samuti oli kahe uuringu võrdluses näha Hea Alguse õpetajate edasiminekut lapsevanematega koostöö valdkonnas. Nimelt märgiti 2016. aastal oluliselt sagedasemaks lapsevanemate viibimist rühmas ja lastega mängimist, lapsevanemate omavahelist suhtlust, vanavanemate kaasatust rühma töösse ning lapsevanematega lapse arengut puudutavate vestluste läbiviimist.

Samas esines üksikuid tegevusi, mille korral olid Hea Alguse õpetajate hinnangud 2016. aastal madalamad kui 2008. aastal. Näiteks kui varem hindasid Hea Alguse õpetajad iga perekonna eripäraga arvestamist ja vanemate nõustamist lapse arengut puudutavates küsimustes sagedaseks, siis 2016. aastal antud hinnangute põhjal teevad nad eespool nimetatut vahetevahel. Samuti oli Hea Alguse õpetajate hinnang oma tegevuse sagedusele võrreldes varasema uuringuga 2016. aastal veidi madalam väite „Lapsed saavad teha valikuid“ korral, kuigi valikute võimaldamine ja lastele vastutuse andmine on üks olulisimaid põhimõtteid lapsekeskse kasvatuse rakendamisel ja lastega suhtlemisel (Bredekamp \& Copple, 1997; Hansen et al., 1997), mida on rõhutatud ka Eesti koolieelse lasteasutuse riiklikus õppekavas (2008). Pereira ja Smith-Adcock (2011) on väitnud, et lapsekeskset kasvatust rakendavad õpetajad oskavad suhelda lastega viisil, mis toetab laste iseseisvust, oskust teha valikuid ja aktsepteerida oma valikute tagajärgi. Seega tuleks lisaks uurida õpetajate ja laste vahelist suhtlust koolieelse lasteasutuse rühmas.

Kõrvutades uuringu tulemusi koolieelse lasteasutuse riiklikus õppekavas (2008) esitatud põhimõtetega, võib öelda, et õpetajad lähtuvad enda hinnangul nendest põhimõtetest oluliselt sagedamini kui varem. Näiteks pakuvad Hea Alguse programmi rakendavad ja mitterakendavad õpetajad lastele sagedamini võimalust algatada teemasid, mida käsitleda, innustavad lapsi sagedamini mõtlema, arutlema, katsetama, suunavad lapsi üksteisega suhtlema ning dokumenteerivad iga lapse arengut. Seega võib järeldada, et ópetajad on 
koolieelse lasteasutuse riikliku õppekava kohase lapsekeskse õpikäsituse omaks võtnud ja püüavad sellest oma tegevuses ka lähtuda.

Eraldi võiks esile tuua mitmekultuurilise hariduse aspekti, mida rahvusvaheliselt alushariduses üha enam tähtsustatakse. Mitmekultuurilise õpikeskkonna väärtustamisele on tähelepanu juhitud ka Euroopa alusharidust puudutavates dokumentides (UNESCO, 2000). Varasemates uuringutes on selgunud, et Eesti lasteaiaõpetajad on õpikeskkonna loomisel kõige vähem arvestanud õppekavas esitatud põhimõtet tutvustada teisi rahvusi ja kultuure (Õun, 2009). 2008. aasta uuringus (vt Õun et al., 2010) ilmnes, et nii Hea Alguse programmi rakendavad kui ka mitterakendavad õpetajad korraldavad harva eri kultuure tutvustavaid üritusi, mis oli uuringus üks madalaima hinnanguga tulemusi. 2016. aasta uuringus oli õpetajate hinnang selle tegevuse kohta aga oluliselt kõrgem ning ka lastes austuse ja sallivuse kasvatamisega väideti end tegelevat sagedamini. Samas oli mõlema valimigrupi hinnang varasemast oluliselt madalam väitele, et õpetaja arvestab iga perekonna eripäraga. Sellist tulemust võib osaliselt selgitada sellega, et suurenenud on eri keele- ja kultuuritaustaga lasteaialaste arv, mis on pannud õpetajaid kahtlema oma võimekuses arvestada kõikide perekondade eripäraga. Näiteks, 2017. aastal oli statistika järgi Eestisse elama paigutatud 120 pagulast (Ümberpaigutatud ..., 2017), seega on õpetajatel üha enam vaja toime tulla laste ja peredega, kes on harjumuspärasest erineva taustaga. Uus reaalsus nõuab kõigilt head kohanemisvõimet (Riigi ..., 2016), samas on uuringud (Berthelsen \& Karuppiah, 2011; Jokikokko \& Karikoski, 2016; Nagasa, 2014) näidanud, et õpetajad vajavad ka lisateadmisi teise keeleja kultuuritaustaga laste ning nende perede toetamisel, sest sisserännanud õppijate oskusi ja perede tausta arvestades on vaja rakendada uusi õpetusviise (Brown, 2014). Niisiis vajab mitmekultuurilise hariduse aspekt alushariduse õppekava rakendamise kontekstis edasist uurimist, sest me elame globaliseeruvas maailmas, kus inimeste liikumine riigist riiki on üha tavapärasem.

Võrreldes artiklis tutvustatud uuringu tulemusi Kimeri, Tuule ja Õuna (2016) korraldatud uuringu omadega, selgus, et nende tulemused on omavahelises kooskõlas, mis viitab sellele, et õpetajad peavad oluliseks järgida lapsekeskse kasvatuse põhimõtteid ning nende endi sõnul juhinduvad nad nendest põhimõtetest ka oma pedagoogilises tegevuses. Uuringu piiranguks on aga õpetajate subjektiivsed hinnangud enda tegevusele, mis ei anna infot, kas nende arusaamad enda tegevusest rakenduvad ka praktilises õppe- ja kasvatusprotsessis. Näiteks on Neudorf jt (2017) leidnud, et õpetajad küll väärtustavad üldoskuste kujundamist kui lapsekeskse kasvatuse üht olulist osa kõrgelt, kuid tegevuste leidmine nende üldoskuste saavutamiseks ei ole nende jaoks alati väga lihtne. Ka eespool kirjeldatud Kimeri, Tuule ja Õuna (2016) uuring ning mõned rahvusvahelised uuringud (vt Kwon, 2003; Niikko \& Havu-Nuutinen, 
2009) osutavad ebakõlale õpetajate uskumuste ja praktika vahel - lapsekeskse kasvatuse väärtustamine ei tähenda automaatselt seda, et õpetaja oma tegevuses neist põhimõtetest ka tegelikult lähtub. Seepärast on riikliku õppekava rakendumise huvides oluline jätkata õpetajate tegevuse vaatlusi, tuvastamaks, kas ebakõla õpetajate uskumuste ning praktika vahel tuleb esile vaid üksikute õpetajate puhul või on see pigem üldlevinud probleem. Viimasel juhul tuleks püüda välja selgitada selle ebakõla põhjused ning sellele teabele tuginedes valida strateegia õpetajate toetamiseks. Näiteks kui selgub, et õpetajad on veendunud, et nende tegevus vastab riiklikus õppekavas soovitatule, ning seetõttu ei näe nad enam vajadust midagi teisiti teha, siis tuleks anda neile rohkem konstruktiivset tagasisidet nende tegevuse kohta ning innustada neid oma tegevust süstemaatiliselt reflekteerima, et liikuda lapsekeskse õpetuse poole.

Kui õpetajatel puuduvad teadmised ja oskused oma praktika muutmiseks, siis vajavad nad ka praktilisi näiteid lapsekeskse kasvatuse rakendamise kohta. Riiklikus õppekavas on rõhutatud lapsekeskse kasvatuse tähtsust, kuid ei ole kirjeldatud konkreetseid tegevusi ega koostatud kriteeriume, mis lapsekeskset kasvatust iseloomustavad. Seega saavad õpetajad ise valida õppemeetodid ja võimalused, kuidas lapsekeskset kasvatust rakendada ja enda tegevust hinnata. OECD (2012) alushariduse aruandes soovitatakse määrata kindlaks lasteasutuste kvaliteedi eesmärgid ja kehtestada miinimumstandardid, mis aitavad tagada alushariduse kvaliteeti. Kui õppeasutuste õppekavades on rõhutatud lapsekeskse kasvatuse rakendamise vajalikkust ja personalil on vabadus valida sobivaid tegevusi, on lapsekeskse mudeli rakendamiseks vaja hea haridusega töötajaid, kes mõistavad lapse arengut. Eestis on õpetajad küllaltki hea pedagoogilise ettevalmistusega, aga kuna riiklik õppekava annab kätte vaid väga üldise suuna ning õpetajatel on suur vabadus nende suuniste tõlgendamisel, siis võib õpetajate ettekujutus oodatavast lapsekesksest praktikast olla väga erinev. Seega oleks Eestis vaja koostada riiklikku õppekava täiendavad juhendmaterjalid ja praktilised soovitused lapsekeskse kasvatuse rakendamiseks lasteaedades. Peale koolituste ja tugimaterjalide on õppekava arendamisel tähtis ka pidev kollegiaalne tugi ja koostöö teiste õpetajatega (Ugaste, Tuul, Mikser, Neudorf, \& Jürimäe, 2016).

Uuringu tulemuste tõlgendamisel tuleb arvestada ka mõningate piirangutega. Nimelt võisid Hea Alguse programmi rakendavate ja mitterakendavate õpetajate hinnangutes 2008. aastal leitud erinevused tuleneda osaliselt sellest, et kõrgharidusega õpetajate osakaal Hea Alguse õpetajate valimis oli suurem kui Hea Alguse programmi mitterakendavate õpetajate valimis. Sellegipoolest ei saa väita, et õpetajate haridustase mõjutas õpetajate hinnanguid rohkem kui Hea Alguse programmi järgimine või mittejärgimine, sest eri haridustasemega õpetajate hinnangute võrdlusel ilmnesid statistiliselt olulised erinevused vaid 
viies väites 67st, samas kui Hea Alguse õpetajate hinnangud olid Hea Alguse programmi mitterakendavate õpetajate hinnangutest statistiliselt olulisel määral kõrgemad enamiku väidete korral (vt Õun et al., 2010). Kindlasti tuleneb aga uuringust vajadus edaspidi põhjalikumalt analüüsida erinevate taustatunnuste koosmõju hinnangutele, mis on õpetajad enda tegevusele andnud, sest õpetajate arusaamad, uskumused ja tegevusmustrid kujunevad välja paljude mõjurite koostoimel.

\section{Kasutatud kirjandus}

Alushariduse raamõppekava kinnitamine (1999). Riigi Teataja I 1999, 80, 737. Külastatud aadressil https://www.riigiteataja.ee/akt/77809.

Bainbridge, A. (2007). Children's learning. In A. D. Nurse (Ed.), The new early years professional: Dilemmas and debates (pp. 44-67). London: Routledge.

Berthelsen, D., \& Karuppiah, N. (2011). Multicultural education: The understandings of preschool teachers in Singapore. Australasian Journal of Early Childhood, 36(4), $38-42$.

Bredekamp, S., \& Copple, C. (1997). Developmentally appropriate practice in early childhood programs. Washington: National Association for the Education of Young Children.

Brown, K. D. (2014). Multicultural teaching in the early childhood classroom: Approaches, strategies, and tools, pre-school to 2nd grade. Eesti Haridusteaduste Ajakiri, 2(2), 237-241. https://doi.org/10.12697/eha.2014.2.2.09

Buchanan, T. K., Burts, D. C., Bidner, J., White, V. F., \& Charlesworth, R. (1998). Predictors of the developmental appropriateness of the beliefs and practices of first, second, and third grade teachers. Early Childhood Research Quarterly, 13(3), 459483. https://doi.org/10.1016/S0885-2006(99)80052-0

Chung, S., \& Walsh, D. J. (2000). Unpacking child-centredness: A history of meanings. Journal of Curriculum Studies, 32(2), 215-234. https://doi.org/10.1080/002202700182727

Cohen, J. (1977). Statistical power analysis for the behavioral sciences (rev. ed.). Hillsdale: Lawrence Erlbaum Associates.

Coughlin, P. A., \& Walsh, K. B. (1996). Hea Alguse algklasside programm lastele ja nende peredele. Tartu: Pere ja Kodu.

Doddington, C., \& Hilton, M. (2007). Child-centred education: Reviving the creative tradition. London: SAGE Publication.

Edwards, C. P., Sheridan, S. M., \& Knoche, L. (2008). Parent engagement and school readiness: Parent-child relationships in early learning. Faculty Publications, Department of Child, Youth, and Family Studies. Retrieved from http://digitalcommons.unl.edu/famconfacpub/60

Ertmer, P. A., \& Newby, T. J. (1993). Behaviourism, cognitivism, constructivism: Comparing critical features from an instructional design perspective. Performance Improvement Quarterly, 6(4), 50-72.

https://doi.org/10.1111/j.1937-8327.1993.tb00605.x 
Erwin, J. E., \& Kipness, N. A. (1997). Fostering democratic values in inclusive early childhood settings. Early Childhood Education Journal, 25(1), 57-60.

https://doi.org/10.1023/A:1025642116800

European Commission (2014). Proposal for key principles of a quality framework for early childhood education and care. Report of the working group on early childhood education and care under the auspices of the European Commission. Brussels: European Commission.

Hansen, K. A., Kaufmann, R. K., \& Walsh, K. B. (1997). Hea Alguse lasteaedade programm. Tartu: Avatud Ühiskonna Instituut.

Havlinova, M., Hejduk, E., Kozova, N., Sulcova, E., Tomasek, L., \& Weinholdova, E. (2004). Measuring psychosocial outcomes in the Step by Step program. Educating Children for Democracy, 6, 20-25.

ISSA (2002). ISSA teacher standards observation form. Hungary: International Step by Step Association.

ISSA (2008). Annual report 2007-2008. Learning and growing together. Hungary: International Step by Step Association.

ISSA (2010). Competent educators of the 21st century. ISSA's principles of quality pedagogy. Hungary: Internal Step by Step Association.

Jeynes, W. H. (2007). American educational history: School, society, and the common good. Thousand Oaks: SAGE Publications.

Jokikokko, K., \& Karikoski, H. (2016). Exploring the narrative of a Finnish early childhood education teacher on her professional intercultural learning. Varhaiskasvatuksen Tiedelehti. Journal of Early Childhood Education Research, 5(1), 92-114.

Kazimade, E. M., Mikailova, U., Neumann, M. J., \& Valdiviezo, L. (2003). Evaluation of the Step by Step program in Azerbaijan. Educating Children for Democracy, 5, $25-31$.

Kelly, T. (2010). Child-centered curriculum. In C. Kridel (Ed.), Encyclopedia of curriculum studies (pp. 108-109). Thousand Oaks: SAGE Publications.

Kimer, M., Tuul, M., \& Õun, T. (2016). Implementation of different teaching approaches in early childhood education practices in Estonia. Early Years, 36(4), 368-382. https://doi.org/10.1080/09575146.2015.1118443

Kinos, J., \& Pukk, M. (2010). Lapsest lähtuv kasvatus. Tallinn: Tea Kirjastus.

Klaus, S. (2004). Stepping into the future: A history of the Step by Step program. Educating Children for Democracy, 8, 3-14.

Koolieelse lasteasutuse riiklik õppekava (2008). Riigi Teataja I 2008, 23, 152. Külastatud aadressil https://www.riigiteataja.ee/akt/12970917.

Kronqvist, E.-L. (2011). Varhaispedagogiikan kehityspsykologinen perusta. E. Hujala \& L. Turja (toim.), Varhaiskasvatuksen käsikirja (s. 13-30). Jyväskülä: PS-kustannus.

Kwon, Y. I. (2003). A comparative analysis of preschool education in Korea and England. Comparative Education, 39(4), 479-491. https://doi.org/10.1080/0305006032000162048

Kwon, Y. I. (2004). Early childhood education in Korea: Discrepancy between national kindergarten curriculum on practices. Educational Review, 56(3), 297312. https://doi.org/10.1080/0013191042000201208

Lapse õiguste konventsioon (1996). Riigi Teataja II 1996, 16, 56. Külastatud aadressil https://www.riigiteataja.ee/akt/24016. 
Lee, I. F., \& Tseng, C. L. (2008). Cultural conflicts of the child-centered approach to early childhood education in Taiwan. Early Years: Journal of International Research and Development, 28(2), 183-196. https://doi.org/10.1080/09575140802163600

Murphy, B. (2004). Practice in Irish infant classrooms in the context of the Irish Primary School Curriculum (1999): Insights from a study curriculum implementation. International Journal of Early Years Education, 12(3), 245-257. https://doi.org/10.1080/0966976042000268717

Männamaa, I. (2006). Hinda tööd, väärtusta ametit. Käsiraamat ópetajale. Tartu: Hea Algus.

Nagasa, K. (2014). Perspectives of elementary teachers on refugee parent-teacher relations and the education of their children. Journal of Educational Research and Innovation, 3(1), 1-16.

Neudorf, E., Ugaste, A., Tuul, M., \& Mikser, R. (2017). Lasteaiaõpetajate uskumused seoses laste üldoskuste arendamisega riikliku õppekava alusel: lisaseletus lasteaia koolistumise põhjustele. Eesti Haridusteaduste Ajakiri, 5(2), 54-79. https://doi.org/10.12697/eha.2017.5.2.03

Niikko, A., \& Havu-Nuutinen, S. (2009). In search of quality in Finnish pre-school education. Scandinavian Journal of Educational Research, 53(5), 431-445. https://doi.org/10.1080/00313830903180711

OECD (2001). Starting Strong. Luxembourg: OECD Publishing. https://doi.org/10.1787/9789264192829-en

OECD (2006). Starting Strong II: Early childhood education and care. Paris: OECD Publishing. https://doi.org/10.1787/9789264035461-en

OECD (2012). Starting Strong III: A quality toolbox for early childhood education and care. Paris: OECD Publishing. https://doi.org/10.1787/9789264123564-en

Pereira, J. K., \& Smith-Adcock, S. (2011). Child-centered classroom management. Action in Teacher Education, 33(3), 254-264.

https://doi.org/10.1080/01626620.2011.592111

Persson, S., \& Tallberg Broman, I. (2017). Early childhood education and care as a historically located place: The significance for parental cooperation and the professional assignment. Nordic Journal of Studies in Educational Policy, 3(2), 189199. https://doi.org/10.1080/20020317.2017.1352440

Peterson, T., Veisson, M., Hujala, E., Härkönen, U., Sandberg, A., Johansson, I., \& Kovacsne Bakosi, E. (2016). Professionalism of preschool teachers in Estonia, Finland, Sweden and Hungary. European Early Childhood Education Research Journal, 24(1), 136-156. https://doi.org/10.1080/1350293X.2015.1120529

Pinnegar, S., \& Erickson, L. (2010). Teacher-centered curriculum. C. Kridel (Ed.), Encyclopedia of curriculum studies (pp. 849-850). Thousand Oaks: SAGE Publications.

Powell, D. R., Son, S.-H., File, N., \& San Juan, R. R. (2010). Parent-school relationships and children's academic and social outcomes in public school pre-kindergarten. Journal of School Psychology, 48(4), 269-292.

https://doi.org/10.1016/j.jsp.2010.03.002

Põlluste, M. (2014). Hea Algus lasteaias. Pärnu Lasteaia Päikesejänku lugu. H. Tammiste (koost.), Tarkus tuleb tasapisi. Valik aktiivõppe strateegiaid lasteaias ja koolis (lk 38-60). Tartu: Atlex. 
Riigi ja kohalike omavalitsuste valmisolek võtta vastu rahvusvahelise kaitse taotlejaid ja saanuid. Kas riik on valmis täitma endale seadusega võetud kohustusi? Riigikontrolli aruanne Riigikogule (2016). Külastatud aadressil https://www.valitsus.ee/ sites/default/files/content-editors/failid/aruanne_pagulased_18.01.2016.pdf.

Ruto-Korir, R. C. (2010). Preschool teachers' beliefs of developmentally appropriate educational practices (Doctoral dissertation). Pretoria: University of Pretoria.

Ruus, V.-R., \& Sarv, E. S. (2000). Changes in Estonian school curricula (1987-1999) and thoughts about the future. In B. T. Peck \& A. Mays (Eds.), Challenge and change in education: The experience of the Baltic States in the 1990's (pp. 139-153). New York: Nova Science Publishers.

Saracho, O. N., \& Spodek, B. (2003). Recent trends and innovations in the early childhood education curriculum. Early Child Development and Care, 173(2-3), 175183. https://doi.org/10.1080/03004430303095

Sarv, E. S. (1999). Analysis in the Estonian context. H. Niemi (Ed.), Moving horizons in education: International transformations and challenges of democracy (pp. 39-67). Helsinki: University of Helsinki.

Spillane, J. P., Reiser, B. J., \& Reimer, T. (2002). Policy implementation and cognition: Reframing and refocusing implementation research. Review of Educational Research, 72(3), 387-431. https://doi.org/10.3102/00346543072003387

Stipek, D., \& Byler, P. (1997). Early childhood teachers: Do they practice what they preach? Early Childhood Research Quarterly, 12(3), 305-325.

https://doi.org/10.1016/S0885-2006(97)90005-3

Stipek, D., \& Byler, P. (2004). The early childhood classroom observation measure. Early Childhood Research Quarterly, 19(3), 375-397. https://doi.org/10.1016/j.ecresq.2004.07.007

Stipek, D., \& Byler, P. (2005). The early childhood classroom observation measure: Coding manual. Connecticut: University of Stanford.

Sylva, K., Melhuish, E., Sammons, P., Siraj-Blatchford, I., \& Taggart, B. (2004). The effective provision of pre-school education [EPPE] project. Technical paper 12. The final report: effective pre-school education. London: University of London.

Treier, J. (2004). Alushariduse õppekava rakendumine (kutsemagistritöö). Tartu: Tartu Ülikool.

Tzuo, P. W. (2007). The tension between teacher control and children's freedom in a child-centered classroom: Resolving the practical dilemma trough a closer look at the related theories. Early Childhood Education Journal, 35(1), 33-39. https://doi.org/10.1007/s10643-007-0166-7

Tuul, M. (2017). Lasteaiaõpetajate arusaamad õppekavadest ja laste õppimisest ning hinnang õpetaja pedagoogilisele tegevusele lapsekeskse kasvatuse kontekstis (doktoritöö). Tallinn: Tallinna Ülikool.

Tuul, M., Mikser, R., Neudorf, E., \& Ugaste, A. (2015). Estonian preschool teachers' aspirations for curricular autonomy - the gap between an ideal and professional practice. Early Child Development and Care, 185(11-12), 1845-1861. https://doi.org/10.1080/03004430.2015.1028387

Ugaste, A., Tuul, M., Mikser, R., Neudorf, E., \& Jürimäe, M. (2016). Koolieelse lasteasutuse õpetajate kui õppekava arendajate kogemused, ootused ja hinnangud. Eest $i$ Haridusteaduste Ajakiri, 4(1), 92-118. https://doi.org/10.12697/eha.2016.4.1.04 
Ugaste, A., \& Õun, T. (2007). Teachers' experiences in child-centered education in Estonia. Young Children, 62(6), 54-56.

Ugaste, A., Oun, T., \& Tuul, M. (2008). Implementation of a child-centred approach in post-socialist society. J. Mikk, M. Veisson, \& P. Luik (Eds.), Reforms and innovations in Estonian education (pp. 157-171). Frankfurt am Main: Peter Lang Verlag.

UNESCO (2000). Framework for action on values education in early childhood. International decade for a culture of peace and nonviolence for the children of the world. Paris: UNESCO.

Vonta, T. (2004). Teacher evaluation using ISSA standards: A tool for professional development and quality improvement. Educating Children for Democracy, 7, 21-25.

Õun, T. (2009). Quality of learning environments in Estonian preschools. Problems of Education in the 21st Century, 15, 118-124.

Õun, T., Ugaste, A., Tuul, M., \& Niglas, K. (2010). Perception of Estonian preschool teachers about the child-centered activities in different pedagogical approaches. European Early Childhood Education Research Journal, 18(3), 391-406. https://doi.org/10.1080/1350293X.2010.500079

Ümberpaigutatud ja -asustatud pagulaste statistika (2017). Tartu: Haridus- ja Teadusministeerium. Külastatud aadressil https://valitsus.ee/sites/default/files/contenteditors/failid/eestisse_umberpaigutatud_tabel_17.03.2017.pdf. 


\title{
Perception of Step by Step and non-Step by Step preschool teachers about the child-centred activities
}

\author{
Maire Tuul $^{\mathrm{a}}$, Tiia Õun ${ }^{\text {a1 }}$, Uljana Botvina ${ }^{\mathrm{a}}$ \\ a School of Educational Sciences, Tallinn University
}

\section{Summary}

\section{Introduction}

In Estonia, the need to move from adult-directed education to child-centred education has been emphasised for more than 20 years. The transition has been supported by promoting the child-centred Step by Step programme as well as by the introduction of the principles of child-centred education in the national curricula of Estonian preschool education (Tuul, 2017). Preschool child care institutions started to implement the renewed curriculum in 2009, and it was assumed that teachers' understandings of how to manage a highquality learning process as well as how to improve their teaching practice by the help of the new curriculum would soon become similar. However, in a written questionnaire to 25 teachers and observations of their activities demonstrated that teachers were applying the principles of child-centred education only partially, although in their own words, their pedagogical work was primarily based on the child-centred approach (Kimer et al., 2016). Since the number of participants in that study was small, the question emerged about the extent to which the findings of this study reflected the general tendencies in the field of preschool education. If research confirms the teachers' belief that their everyday work is consistent with the principles of child-centred education, then the result that teachers' activities reflect child-centred education only partially indicate that teachers might lack the necessary knowledge and skills to change their pedagogical practice (Spillane et al., 2002).

Therefore, we decided to repeat the study conducted in 2008 based on the ISSA standard to find out: 1) What are the teachers' assessments of their own work in five areas: communication between the teacher and the child, cooperation with parents, the planning of the teacher's work, the use of child-centred teaching methods and the development of the learning environment? 2) What are the differences between teachers following the Step by Step approach and

School of Educational Sciences, Tallinn University, Narva Street 25, 10120 Tallinn, Estonia; tiiaoun@tlu.ee 
those not following it? 3) How do the results of the 2016 study differ from the results of the 2008 study? Based on the findings of the aforementioned study (see Kimer et al., 2016), as well as the results of a written survey of 347 class teachers conducted in 2013, according to which teachers were in general very satisfied with both the national curriculum of preschool child care institutions as well as with the curriculum of their kindergarten (Tuul et al., 2015), we hypothesized that 1) teachers' assessments of their activities in the context of child-centred education are high and 2) there are no significant differences between teachers following the Step by Step approach and teachers who do not follow it.

\section{Methodology}

Since we wanted to conduct a comparative study, we then used, similarly to the previous study (see Õun et al., 2010), a structured written questionnaire compiled on the basis of the international standard of assessing the activities of teachers following the Step by Step approach (ISSA, 2002). The questionnaire consisted of 67 questions (divided into five areas) about teachers' activities assessed on the 5-point Likert scale where the teachers had to assess the frequency of their daily activities on a scale from " 1 -never" to " 5 -always".

The sample was selected by following the principles of the study in 2008 . Namely, we attempted to send the questionnaire to as many teachers as possible who followed the Step by Step approach, and the teachers not following the approach we chose from the same regions. Ninety-nine Step by Step teachers and 106 teachers who did not follow the Step by Step approach responded. By their work experience, age and educational level both groups of teachers were relatively similar. The data were analysed by the statistics programme SPSS 19.0. We used descriptive statistics, the Student's $t$-test and Chi-square test, and calculated Cohen's $d$. The reliability coefficient Cronbach's Alpha was used to form the aggregate variables of areas.

\section{Key findings and discussion}

The study revealed that teachers assessed their pedagogical activity in the context of child-centred education very highly in almost all studied areas $(M \geq 4.4$ in 5-point scale). Thus, in general, we can say that the first hypothesis was confirmed. The only exception was the cooperation with parents, where teachers' mean score on the 5-point scale was 3.7. The tendency of preschool teachers in Estonia assessing their cooperation with parents lower than their activities in 
other areas of their work also appeared in the study by Peterson et al. (2016). As some researchers (Edwards et al., 2008; Powell et al., 2010; Sylva et al., 2004) have pointed out, the inclusion of family members in the activities of the preschool has a positive impact on the adaptation of children and on their social and cognitive achievements. Thus, the cooperation with families is an area that needs further examination.

The comparison of the assessments of the teachers following the Step by Step approach and those not following this approach revealed that their assessments were similar, so the second hypothesis was also confirmed. Compared to 2008, in 2016 the assessments of those teachers not following the Step by Step approach were statistically significantly higher in all areas, and the assessments of teachers following the Step by Step approach were statistically significantly higher in the areas of planning teachers' work and communication between the teacher and the child. The greatest progress in the assessments of teachers not following the Step by Step approach could be seen in the area of developing the learning environment and cooperation with parents, in which the scores were the lowest in 2008. While in the area of developing the learning environment, the assessments of teachers not following the Step by Step approach are also higher regarding all variables in 2016 compared to 2008, it is not the case with cooperation with parents. Namely, the participants of the 2008 study marked more often than those in the 2016 study that they are attentive and polite with all parents, that they consider the specificities of every family, that they greet and advise parents and visit children's homes. The respondents in the 2016 study said that they almost never visit children's homes, and parents are advised and the specificities (nationality, religion, special needs) of every family are only sometimes considered. Such a result may partly be explained by the increasing number of children with a different native language and cultural background at preschools. Studies (Berthelsen \& Karuppiah, 2011; Jokikokko \& Karikoski, 2016; Nagasa, 2014) have demonstrated that teachers need additional knowledge in supporting children with a different linguistic and cultural background.

To summarise, the results of this study are consistent with the results of the study conducted in 2014 by Kimer et al. (2016) and suggest that all teachers, regardless of the programme used, have adopted the principles established in the national curriculum for preschool child care institutions. However, some international studies (see Kwon, 2003; Niikko \& Havu-Nuutinen, 2009) indicate an inconsistency between teachers' beliefs and work practice. A high assessment of child-centred education does not automatically mean that teachers also follow these principles in their work. Thus, in the interests of implementing the national curriculum, it is important to continue observations of 
teachers' work in order to see whether the inconsistency is present only in the case of single teachers or whether it is a widespread problem. In the latter case, it is important to ascertain the reasons for this inconsistency, and based on this information choose a strategy to support teachers.

Keywords: teachers' assessments, Step by Step, child-centred education, preschool, preschool education 